IZA DP No. 8042

Why Do Some Motorbike Riders Wear a Helmet and Others Don't? Evidence from Delhi, India

Michael Grimm

Carole Treibich

March 2014 


\title{
Why Do Some Motorbike Riders Wear a Helmet and Others Don't? Evidence from Delhi, India
}

\author{
Michael Grimm \\ Erasmus University Rotterdam, \\ Passau University and IZA \\ Carole Treibich \\ Paris School of Economics, Erasmus University Rotterdam \\ and Aix-Marseille University, CNRS \& EHESS
}

Discussion Paper No. 8042

March 2014

IZA

P.O. Box 7240

53072 Bonn

Germany

Phone: +49-228-3894-0

Fax: +49-228-3894-180

E-mail: iza@iza.org

\begin{abstract}
Any opinions expressed here are those of the author(s) and not those of IZA. Research published in this series may include views on policy, but the institute itself takes no institutional policy positions. The IZA research network is committed to the IZA Guiding Principles of Research Integrity.

The Institute for the Study of Labor (IZA) in Bonn is a local and virtual international research center and a place of communication between science, politics and business. IZA is an independent nonprofit organization supported by Deutsche Post Foundation. The center is associated with the University of Bonn and offers a stimulating research environment through its international network, workshops and conferences, data service, project support, research visits and doctoral program. IZA engages in (i) original and internationally competitive research in all fields of labor economics, (ii) development of policy concepts, and (iii) dissemination of research results and concepts to the interested public.
\end{abstract}

IZA Discussion Papers often represent preliminary work and are circulated to encourage discussion. Citation of such a paper should account for its provisional character. A revised version may be available directly from the author. 


\section{ABSTRACT \\ Why Do Some Motorbike Riders Wear a Helmet and Others Don't? Evidence from Delhi, India}

We focus on helmet use behavior among motorbike users in Delhi. We use a detailed data set collected for the purpose of the study. To guide our empirical analysis, we rely on a simple model in which drivers decide on self-protection and self-insurance. The empirical findings suggest that risk averse drivers are more likely to wear a helmet, there is no systematic effect on speed. Helmet use also increases with education. Drivers who show a higher awareness of road risks are both more likely to wear a helmet and to speed less. Controlling for risk awareness, we observe that drivers tend to compensate between speed and helmet use. The results can provide a basis for awareness-raising policies. Improvements to the road infrastructure bear the risk of leading to risk-compensating behavior.

JEL Classification: D10, I10, I15, K42, R41

Keywords: road safety, helmet use, risky health behavior, self-protection, self-insurance, India

Corresponding author:

Michael Grimm

University of Passau

Innstrasse 29

94032 Passau

Germany

E-mail: michael.grimm@uni-passau.de 
In some states of India, women are exempted from safety rules that mandate motorcycle passengers wear helmets - an exemption that kills or injures thousands each year. Women's rights advocates have argued the exemption springs from a culture-wide devaluation of women's lives. Supporters of the ban say they're just trying to preserve women's carefully styled hair and make-up - which isn't exactly a feminist response.

(Washington Post, October 27, 2013)

\section{Introduction}

Nearly 3,500 people die on the world's roads every day. $90 \%$ of these fatalities occur in developing countries (WHO, 2009). In 2020, road traffic injuries are expected to be ranked third in the global burden of disease (Lopez et al., 2006). Despite these numbers and the related tremendous costs, road mortality is still a neglected public health issue in many low and middle income countries. India accounts for about $10 \%$ of road accident fatalities worldwide. The implied costs are estimated at around 3\% of GDP (Mohan, 2002). In many developing countries, the share of two-wheeled vehicles largely dominates the vehicle fleet. In India this share is around $70 \%$. Not surprisingly motorbike users constitute a large share of all road traffic accident injuries and fatalities; in Delhi for instance more than $30 \%$. Injuries to the head and the neck are the main cause of death, indeed $60 \%$ of All India Institute of Medical Sciences' (AIIMS) admissions — one of the biggest trauma centers in Delhi are road related head injuries (see also Kumar et al., 2008). Medical science stresses the efficiency of helmets in reducing the road related mortality and morbidity. Mandatory helmet use is thus one important policy that governments are recommended to implement in order to reduce road-related fatalities (WHO, 2004, 2006). The effectiveness of such laws, if enforced, has been shown in various contexts (see, e.g., Dee, 2009; French et al., 2009). Despite the formal introduction of such laws in most countries of the world (WHO, 2009), enforcement is however often very weak. Moreover motorbike users are often not aware of the protection that a helmet can provide.

India has had a helmet law since 1988. This national law should be implemented at the State level, yet it is hardly enforced. A major complication comes from the fact that the Sikh community successfully lobbied against this law as their religion requires a turban or at least no other headpiece. Since the exception also applies to Sikh women, and hence it is difficult to distinguish Sikh from other women, the exception was later extended to all women. In 
Delhi less than $25 \%$ of all women wear a helmet when sitting on a motorbike - typically in the poised perched side-saddle position. ${ }^{1}$ For men the share of helmet wearers is significantly higher, but is still far from full coverage. Understanding this heterogeneity, i.e. why some drivers and passengers wear a helmet and others not, is key to design effective interventions to increase helmet use.

Helmet use might be linked to risk aversion, the awareness of road-related risks, income, and as seen above, culture and traditions. Moreover, motorbike riders have various options to protect themselves or to seek insurance. Speed is obviously a second important decision parameter. To understand the behavior of helmet use, we first model this problem theoretically. Relying on the literature of self-insurance and self-protection, we develop a simple model that can be used for comparative static analysis. Based on this analysis we derive hypotheses which we test empirically using a unique data set covering more than 850 motorbike riders and passengers in Delhi. ${ }^{2}$

The remainder of the paper is organized as follows. In section 2 we briefly review the related literature, highlight the existing knowledge gaps and elaborate on the paper's contribution. Section 3 presents the theoretical framework and derives from it testable predictions regarding helmet use and speed. Section 4 introduces the data set. Section 5 shows how we operationalize the empirical tests. Section 6 presents the empirical analysis and discusses the results. Section 7 concludes.

\section{Related literature}

In what follows we briefly review the theoretical literature that considers the role of risk aversion on individual investment in different accident prevention activities. We emphasize in particular the role of risk compensating effects. After that we discuss the related empirical evidence.

Both Peltzman (1975) and Blomquist (1986) modeled the driver's behavior and derived insightful predictions for risk neutral agents. They focused in particular on risk compensation effects, i.e. behavioral responses to exogenous variations in risk. Others enriched such models with explicit consideration of the risk preferences of agents in their behavioral response.

\footnotetext{
${ }^{1}$ Figures derived from a household survey implemented by the authors in Delhi. See below.

${ }^{2}$ This paper builds on Grimm and Treibich (2013) in which we study the determinants of road traffic accident fatalities across Indian states over time.
} 
Dionne and Eeckhoudt (1985) and Bryis and Schlesinger (1990), for example, examined theoretically the impact of increased risk aversion on the optimal levels of self-insurance and self-protection. Self-insurance refers to activities that reduce the severity of a loss. Selfprotection decreases the probability that the loss occurs (Ehrlich and Becker, 1972). In their models the level of self-insurance monotonically increases with risk aversion, while the effect of risk aversion is ambiguous regarding self-protection. In other words, a more risk averse individual will always invest more in self-insurance but it is possible that the individual chooses a lower level of self-protection. Indeed, self-protection reduces the occurrence of a loss but does not reduce the loss in case the bad state occurs. Rather to the contrary, in addition to the loss, wealth is reduced by the increased cost of self-protection, thus leading to an even worse outcome if the bad state occurs. Hence, a higher level of self-protection might be considered as more, not less risky and may explain why a more risk averse individual might decide to invest less in such an activity. Finally, when combining both activities and investigating the influence of risk aversion on a self-insurance-cum-protection activity, a more risk averse individual will invest more in the prevention activity, if the marginal loss reduction in the bad state out-weights the marginal increase in the cost of the combined activity. This has been shown by Lee (1998).

Peltzman (1975) and Wilde (1982) introduced the idea that individuals may respond to an exogenous increase in safety in a way that it lowers or even annihilates (risk homostasis) the reduced risk. Such reactions are called 'risk compensation effects' and may arise if individuals target a fixed level of risk and therefore prefer taking more risks when their risk environment improves. Some studies empirically tested whether such effects indeed exist. However, these studies typically rely on highly aggregated data and hence potentially suffer from omitted variable bias. Chirinko and Harper Jr. (1993), for example, investigated the effect of improved car safety (measured through an index of safety regulations in relation to improved car safety for occupants since 1966) and of the introduction of the speed limit of $55 \mathrm{mph}$ in the US. Their econometric estimates revealed that the offsetting behavior is quantitatively important and attenuates the effects of safety regulations on occupant fatalities. Using a modified expected utility model, the authors showed that the impact of regulatory policies depends on a mix of protection (direct effect of the regulation), substitution (offsetting behavior) and cognition elements. Based on Virginia State Police accident reports of 1993, Peterson et al. (1995) also 
showed that air-bag-equipped cars tend to be driven more aggressively, thus offsetting the effect of the air-bag for drivers and increasing the risk of death for others. However, other studies did not find any evidence of such risk-compensating effects (Lund and Zador, 1984; Lund and O'Neill, 1986).

To circumvent problems inherent in the use of aggregate data, Sobel and Nesbit (2007) used micro-level data from NASCAR (National Association for Stock Car Auto Racing) races. Their setting allowed them to control for problems of enforcement, weather conditions and variation in automobile safety devices. According to their results, NASCAR drivers drive more recklessly in response to an increase in car safety. However, total injuries still fall since the side effect is not large enough to completely offset the direct impact of increased vehicle safety. Obviously, the external validity of this study might be low, as NASCAR drivers might not be very representative of drivers in general. Stetzer and Hofmann (1996) in turn conducted two laboratory experiments to investigate the individual's behavioral response and the perceived risk associated with various driving situations. They found a negative correlation indicating some risk compensation following an increase in environmental safety but this was not large enough to return to the initial level of risk. Messiah et al. (2012) ran a randomized controlled trial in Bordeaux to analyze motorcyclists' chosen speed conditional on helmet adoption. Risk compensation was observed exclusively among men and was of moderate size. Therefore the feedback effect did not offset the benefits of helmet use.

McCarthy and Talley (1999) also provided evidence on risk compensating behaviors. They relied on data from recreational boating. They empirically tested whether an operator's past experience and formal training induces or reduces safety related behaviors. Moreover they investigated the influence of the operator's characteristics and the environmental factors on the attitude adopted by the boat passengers. The authors highlighted that an individual can adjust to risk changes using various strategies. In their study, they focused on two of them: the use of personal flotation devices and alcohol consumption. Passengers seemed to adapt their behavior to their perception of the operator's safety level. Indeed, an operator's boating experience was negatively correlated with flotation device utilization and positively correlated with alcohol consumption by passengers. The authors stressed the implication for motor vehicle travel. In particular, they pointed out that, since the opening of the debate by Peltzman (1975), little work has been done to identify alternative margins that individuals 
use to adjust their safety behavior.

We contribute to the above literature with respect to two dimensions: (i) the influence of risk aversion on prevention activities and (ii) the existence of risk compensating effects. Regarding the first aspect, we derive theoretical predictions regarding the role of risk aversion on a set of different types of prevention efforts. Moreover, thanks to an original dataset of motorbike riders and passengers in Delhi, we are able to test these assumptions empirically. In particular, we focus on the drivers' simultaneous decision-making with respect to selfprotection and self-insurance and how risk preferences affect this trade-off. With respect to the second dimension, we look at the existence of risk compensating effects. An interesting feature of our data is that we also observe passengers. For passengers speed can be seen as exogenously determined if the assumption is made that the driver decides on speed. We are thus able to investigate the relation between a passenger's safety effort and the environment such as the quality of roads and motorbike and driver characteristics. As for the driver, we can examine the relationship between alternative dimensions of safety behaviors and whether they are complements or substitutes.

\section{Theoretical framework}

Building on Dionne and Eeckhoudt (1985) and Bryis and Schlesinger (1990), we investigate the individual decision to invest in self-insurance and self-protection activities using a relatively simple expected utility model. As in Ehrlich and Becker (1972), self-insurance refers to any activity that reduces the loss if an accident occurs, while self-protection refers to any activity that reduces the probability of experiencing an accident.

In our theoretical framework we address three questions: (i) How does risk aversion influence the investment in insurance and protection? (ii) How do motorbike users respond to exogenous changes in safety? (iii) Are protection and insurance complements or substitutes for one another?

We consider two road related attitudes: helmet use and speed. Helmet use can be seen as a self-insurance activity given that a helmet reduces the severity of an injury if an accident 
occurs. ${ }^{3}$ For simplicity, lowering speed is assumed to be a self-protection activity. ${ }^{4}$ While we assume that the drivers of a motorbike choose both helmet use and speed, we assume that passengers only make a decision on helmet use, and take speed as given. We examine these two types of road users in turn. We start with the case of passengers.

\subsection{Passengers}

Consider a risk averse passenger with wealth $W$. With a probability $p$, the passenger is involved in a road accident and with probability $(1-p)$ the passenger is not. If an accident occurs, the passenger faces a loss $I$; however, the passenger can invest in the self-insurance activity to reduce the size of the potential loss. This decision includes whether to use a helmet, the type of helmet and whether for instance the strap is closed. However, helmet use comes at a cost in the form of discomfort. Let $h$ denote the level of self-insurance. $I(h)$ represents the effect of a helmet on the severity of an injury, which is obviously assumed to decrease with the chosen level of self-insurance, $I^{\prime}(h)<0$. Discomfort, $c(h)$, is assumed to increase monotonically with $h$. Preferences, $U(\cdot)$, are assumed to be of the von Neumann-Morgenstern type, where $U^{\prime}>0$ and $U^{\prime \prime}<0$.

The individual's expected utility can be written as:

$$
E U=p \cdot U[W-c(h)-I(h)]+(1-p) \cdot U[W-c(h)] .
$$

The first order condition for maximizing (1) with respect to $h$ is:

$$
\frac{\partial E U}{\partial h}=-p \cdot\left[c^{\prime}(h)+I^{\prime}(h)\right] \cdot U^{\prime}(B)-(1-p) \cdot c^{\prime}(h) \cdot U^{\prime}(G)=0
$$

where $G=W-c(h)$ and $B=W-c(h)-I(h)$.

Note that in order to have an interior solution, we must have $\left[c^{\prime}(h)+I^{\prime}(h)\right]<0$, i.e. the magnitude of the potential marginal benefit, $-I^{\prime}(h)$, must be at least as high as the marginal

\footnotetext{
${ }^{3}$ Indeed Liu et al. (2008) reviewed 53 studies that investigate the efficiency of helmets. They found that on average the use of a standardized helmet reduces the risk of death and serious injuries by $40 \%$ and $70 \%$ respectively. Goldstein (1996) stressed however that there is a 'head-neck injury trade-off', i.e. given the weight of a helmet, the use of a helmet increases the risk of neck injuries.

${ }^{4}$ We acknowledge that it could also be assumed that speed is rather a self insurance-cum-protection activity, since speed may impact on both the frequency and severity of road accidents. However, to ease the resolution of the system of equations we opt for this simplification.
} 
cost following the increase in $h, c^{\prime}(h)$. Indeed, the passenger will certainly not choose a level of helmet-use for which the perceived marginal discomfort exceeds the marginal benefit. Given the concavity of the utility function, the second-order condition for the maximization problem can be easily derived.

\subsubsection{Risk aversion}

Let $h_{U}$ denote the optimal level of insurance for the passenger with utility function $U$ defined above. Let us now consider a second, more risk averse, passenger with a utility function $V$ which exhibits higher risk aversion than $U$, i.e. $V(\cdot)$ is a concave increasing transformation of $U(\cdot)$, hence $V(\cdot)=g[U(\cdot)]$, with $g^{\prime}>0$, and $g^{\prime \prime}<0$ (Pratt, 1964).

Assuming the same wealth prospect and choice set as (2) but taking into account the preferences of the more risk averse individual, we obtain:

$$
\frac{\partial E V}{\partial h}=-p \cdot\left[c^{\prime}(h)+I^{\prime}(h)\right] \cdot g^{\prime}(U(B)) \cdot U^{\prime}(B)-(1-p) \cdot c^{\prime}(h) \cdot g^{\prime}(U(G)) \cdot U^{\prime}(G) .
$$

To see whether a more risk averse individual invests more in self-insurance, we need to evaluate $\frac{\partial E V}{\partial h}$ at $h=h_{U}$. Since, $g^{\prime \prime}<0$, we have $g^{\prime}(U(B))>g^{\prime}(U(G))$. Therefore, when computing $\frac{\partial E V}{\partial h}$ at the optimal point $h_{U}$ (for which we have $\frac{\partial E U}{\partial h}=0$ ) we obtain $\left.\frac{\partial E V}{\partial h}\right|_{h=h_{U}}>0$. In other words, a more risk averse passenger invests more in self-insurance, i.e. helmet use.

\subsubsection{Risk compensating effect}

We consider again the passenger with utility function $U$ and explore an increase in the probability that an accident occurs from $p$ to $q$, where $q>p$. Substituting $q$ in Equation (2), we obtain:

$$
\frac{\partial E U(q)}{\partial h}=-q \cdot\left[c^{\prime}(h)+I^{\prime}(h)\right] \cdot U^{\prime}(B)-(1-q) \cdot c^{\prime}(h) \cdot U^{\prime}(G) .
$$

To see whether the passenger invests more in self-insurance following an exogenous increase in the probability that an accident occurs, we need to evaluate $\frac{\partial E U(q)}{\partial h}$ at $h=h_{U}$. Since $q>p$ and $-\left[c^{\prime}(h)+I^{\prime}(h)\right]>0$ (the condition for an interior solution), we have $-q \cdot\left[c^{\prime}(h)+I^{\prime}(h)\right]>$ $-p \cdot\left[c^{\prime}(h)+I^{\prime}(h)\right]$ and $(1-q) \cdot c^{\prime}(h)<(1-p) \cdot c^{\prime}(h)$. Thus, when computing $\frac{\partial E U(q)}{\partial h}$ at the 
optimal point $h_{U}$, we obtain $\left.\frac{\partial E U(q)}{\partial h}\right|_{h=h_{U}}>0$, i.e. if the probability that an accident occurs increases, the passenger invests more in self-insurance and hence compensate at least partially for the increased risk. In turn, if safety increases exogenously, passengers are thought to invest less. As explained above, in the literature, this effect is called "Peltzman-effect" (Peltzman, 1975).

\subsection{Drivers}

Unlike passengers, drivers are assumed to invest simultaneously in self-insurance (helmet use) and in self-protection (speed). It is assumed that the probability that an accident occurs, $p(s)$, increases with speed, $p^{\prime}(s)>0$. The time spent on the road $t(s)$ in turn decreases with speed, i.e. $t^{\prime}(s)<0$ and thus leaves the driver with a higher level of wealth. As for passengers, we assume that drivers are risk averse and have an increasing concave utility function $U$.

In this case the expected utility is given as:

$$
E U=p(s) \cdot U[W-t(s)-c(h)-I(h)]+(1-p(s)) \cdot U[W-t(s)-c(h)] .
$$

The first order conditions for maximizing (5) with respect to $h$ and $s$ are:

$$
\begin{gathered}
\frac{\partial E U}{\partial h}=-p(s) \cdot\left[c^{\prime}(h)+I^{\prime}(h)\right] \cdot U^{\prime}(B)-(1-p(s)) \cdot c^{\prime}(h) \cdot U^{\prime}(G)=0 \text { and } \\
\frac{\partial E U}{\partial s}=p^{\prime}(s) \cdot[U(B)-U(G)]-t^{\prime}(s) \cdot\left[p(s) \cdot U^{\prime}(B)+(1-p(s)) \cdot U^{\prime}(G)\right]=0 .
\end{gathered}
$$

\subsubsection{Risk aversion}

Again we consider the case of two individuals, i.e. here drivers, with different degrees of risk-aversion, $U$ and $V$ :

$$
\frac{\partial E V}{\partial h}=-p(s) \cdot\left[c^{\prime}(h)+I^{\prime}(h)\right] \cdot g^{\prime}(U(B)) \cdot U^{\prime}(B)-(1-p(s)) \cdot c^{\prime}(h) \cdot g^{\prime}(U(G)) \cdot U^{\prime}(G)
$$

and

$\frac{\partial E V}{\partial s}=p^{\prime}(s) \cdot[g(U(B))-g(U(G))]-t^{\prime}(s) \cdot\left[p(s) \cdot g^{\prime}(U(B)) \cdot U^{\prime}(B)+(1-p(s)) \cdot g^{\prime}(U(G)) \cdot U^{\prime}(G)\right]$. 
To see whether the more risk averse driver invests more in self-insurance and self-protection, we need to compute the sign of Equations (8) and (9) at $h=h_{U}$ and $s=s_{U}$ respectively. The results show that in such a framework a more risk averse individual invests more in self-insurance, while the effect on self-protection is ambiguous. As explained above this is due to the fact that a more risk averse individual invests always more in self-insurance but not necessarily in self-protection. Indeed, self-protection reduces the occurrence of a loss but does not reduce the loss in case the accident occurs. Rather to the contrary, in addition to the loss, wealth is reduced by the increased cost of self-protection, leading to an even worse outcome if the accident occurs. Hence, a higher level of self-protection can be considered as more, not less risky and can explain why a more risk averse individual may not necessarily decide to invest more in such an activity (Dionne and Eeckhoudt, 1985; Bryis and Schlesinger, 1990).

\subsubsection{Risk compensating effect}

Again, we investigate the case of an individual with the utility function $U$ and investigate the influence of a change in the probability that an accident takes place on helmet use by drivers. Such variation may be exogenous (as in the case with passengers) or endogenous. An exogenous increase in the probability of accident may occur following the deterioration of road quality, increased traffic density or adverse weather conditions. Obviously, just as passengers do, drivers invest more in self-insurance following an exogenous rise in the probability that an accident occurs. In the case of drivers, it is important to note that any change in speed has also wealth effects, as the travel time is altered. The marginal change in helmet use following a marginal change in speed is given by the following cross-derivative:

$$
\begin{aligned}
& \frac{\partial^{2} E U}{\partial h \partial s}=p^{\prime}(s) \cdot\left(-\left[c^{\prime}(h)+I^{\prime}(h)\right] \cdot U^{\prime}(B)+c^{\prime}(h) \cdot U^{\prime}(G)\right)+ \\
& t^{\prime}(s) \cdot\left(p(s) \cdot\left[c^{\prime}(h)+I^{\prime}(h)\right] \cdot U^{\prime \prime}(B)+(1-p(s)) \cdot c^{\prime}(h) \cdot U^{\prime \prime}(G)\right) .
\end{aligned}
$$

Using Equation (6), we obtain the following two equalities: 


$$
\left\{\begin{array}{l}
-\left[c^{\prime}(h)+I^{\prime}(h)\right] \cdot U^{\prime}(B)=\frac{(1-p(s)}{p(s)} \cdot c^{\prime}(h) \cdot U^{\prime}(G) \text { and } \\
p(s) \cdot\left[c^{\prime}(h)+I^{\prime}(h)\right]=-(1-p(s)) \cdot c^{\prime}(h) \cdot \frac{U^{\prime}(G)}{U^{\prime}(B)}
\end{array}\right.
$$

Replacing these two equalities in Equation (10) allows us to derive the sign of the cross derivative at the optimal point $h_{U}$ :

$$
\left.\frac{\partial^{2} E U}{\partial h \partial s}\right|_{h=h_{U}}=\frac{p^{\prime}(s)}{p(s)} \cdot c^{\prime}(h) \cdot U^{\prime}(G)+t^{\prime}(s) \cdot(1-p(s)) \cdot c^{\prime}(h) \cdot\left[U^{\prime \prime}(G)-\frac{U^{\prime}(G)}{U^{\prime}(B)} \cdot U^{\prime \prime}(B)\right]
$$

Assuming a constant relative risk aversion rate $\left(-\frac{U^{\prime \prime}(G)}{U^{\prime}(G)}=-\frac{U^{\prime \prime}(B)}{U^{\prime}(B)}=r\right)$, we find that $\left.\frac{\partial^{2} E U}{\partial h \partial s}\right|_{h=h_{U}}>0$. Therefore, when a driver increases speed, he or she also increases helmet use. In other words, for risk averse drivers, helmet use and higher speed are complements, and hence self-insurance and self-protection activities are substitutes.

\subsubsection{Awareness}

There are different options to model awareness in our framework. The most obvious way is to assume that increased awareness implies that the expected probability of an accident at any speed and the expected gain of helmet use should an accident occur is not underestimated relative to actual figures.

\section{Case \#1: Raising the expected probability that an accident occurs at any speed level}

We denote the initial probability $p$ and the probability after awareness has risen $q_{A}$, i.e. $q_{A}>p$. Hence, we substitute in Equations (6) and (7) $p$ by $q_{A}$ and obtain:

$$
\begin{gathered}
\frac{\partial E U_{1}}{\partial h}=-q_{A}(s) \cdot\left[c^{\prime}(h)+I^{\prime}(h)\right] \cdot U^{\prime}(B)-\left(1-q_{A}(s)\right) \cdot c^{\prime}(h) \cdot U^{\prime}(G) \text { and } \\
\frac{\partial E U_{1}}{\partial s}=q_{A}^{\prime}(s) \cdot[U(B)-U(G)]-t^{\prime}(s) \cdot\left[q_{A}(s) \cdot U^{\prime}(B)+\left(1-q_{A}(s)\right) \cdot U^{\prime}(G)\right] .
\end{gathered}
$$


In this case, the weight that is associated with the net marginal gain of using a helmet and being involved in an accident increases $\left(q_{A}>p\right)$ while the one associated with the marginal cost of wearing a helmet in the good state decreases $\left(\left(1-q_{A}\right)<(1-p)\right)$. Hence, a driver with a higher (less downward biased) awareness level invests more in helmet use.

Regarding the chosen speed level, as was the case with the decision on helmet usage, the weight associated with the marginal utility derived in the bad state increases while the one associated with the marginal utility derived in the good state decreases. This leads to an increase in the expected marginal gain of higher speed in terms of traveling time. Therefore the effect of increased awareness on speed depends on whether the utility loss induced by a marginal change in the probability that an accident occurs reinforces or compensates the first effect. If a more aware driver thinks that a marginal increase in speed modifies less the probability of being involved in an accident $q_{A}^{\prime}<p^{\prime}$, the driver invests less in self-protection and travel at a higher speed than a less aware driver. Indeed, in that case the loss in utility and the expected gain in traveling time reinforce one another and $\frac{\partial E U_{1}}{\partial s} \mid s=s_{U}>0$.

\section{Case \#2: Raising the expected loss if an accident occurs for any level of helmet use}

Now we denote the initial expected loss $I(h)$ and the expected loss after awareness has increased $I_{A}(h)$, i.e. , $I_{A}(h)>I(h)$ and hence $B_{A}<B, U\left(B_{A}\right)<U(B), U^{\prime}\left(B_{A}\right)>U^{\prime}(B)$. We substitute again in Equations (6) and (7) and obtain:

$$
\begin{gathered}
\frac{\partial E U_{2}}{\partial h}=-p(s) \cdot\left[c^{\prime}(h)+I^{\prime}(h)\right] \cdot U^{\prime}\left(B_{A}\right)-(1-p(s)) \cdot c^{\prime}(h) \cdot U^{\prime}(G) \text { and } \\
\frac{\partial E U_{2}}{\partial s}=p^{\prime}(s) \cdot\left[U\left(B_{A}\right)-U(G)\right]-t^{\prime}(s) \cdot\left[p(s) \cdot U^{\prime}\left(B_{A}\right)+(1-p(s)) \cdot U^{\prime}(G)\right] .
\end{gathered}
$$

In this case, the level of wealth in the bad state is reduced $\left(B_{A}<B\right)$ because of the increased severity of injuries. Therefore, given the concavity of the utility function, a marginal increase of consumption at $B_{A}$ is higher than at point $B$. If Equation (14) is evaluated at the optimal point $h=h_{U}$, we obtain $\frac{\partial E U_{2}}{\partial h} \mid h=h_{U}>0$, i.e. a higher expected loss induces a higher level of helmet use.

Regarding the chosen level of speed, the higher expected level of injuries implies a larger 
loss in terms of wealth leading to both a greater difference in utilities between the two states of the world $\left(U(G)-U\left(B_{A}\right)>U(G)-U(B)\right)$ and a higher marginal utility in the bad state $\left(U^{\prime}\left(B_{A}\right)>U^{\prime}(B)\right)$. Given the former, a marginal increase in speed increases the loss. Moreover, the marginal increase in speed also raises the level of gain in terms of travelling time due to the latter effect. Hence, again, the effect of an increase in the expected level of injuries on speed is ambiguous. Note that in this case the utility of helmet use remains the same, i.e. $I^{\prime}(h)$ is constant.

\section{Data}

\subsection{General presentation}

During the months July to September 2011 we conducted a household survey in Delhi to collect information from motorbike riders and pillion passengers regarding their behavior when using the motorbike including helmet use and speed, their degree of risk aversion and risk awareness. In addition the survey collected socio-demographic and economic characteristics, information on insurance coverage as well as characteristics of the motorbike in use. To ensure representativeness in the survey with respect to Delhi's population, the following sampling design was applied: (i) Delhi was divided into five zones, (ii) in each zone, ten polling booths were randomly drawn, (iii) the location of these polling booths were taken as starting points from which every fifth household was selected for an interview. Around each polling booth, 30 households were interviewed. In total 1,502 households were surveyed. In 545 households at least one member had used a motorbike in the past four weeks. These households were given a long questionnaire. All other households only received a short questionnaire. ${ }^{5}$ In households with at least one motorbike user, up to three, either drivers or passengers, were selected. On average, there were two eligible members per household. 212 selected individuals refused to answer to the questionnaire, leading to a final sample of 902 individuals which corresponds to a response rate of $81 \%$. Yet, among those who have answered to our survey, there are respondents who could not or did not want to answer to some of the questions. We decided to use in our analysis always the largest possible sample. However we show that our results across different specifications are robust to the exact sample chosen. We also show in the appendix, a

\footnotetext{
${ }^{5}$ The short questionnaire only includes basic socio-demographic information.
} 
probit model in which we regress for drivers and passengers a dummy variable "having at least one missing variable" on a set of basic socio-demographic and socio-economic variables (Table A1). It can be seen that for male drivers, none of these variables is significant, suggesting that non-reporting is rather random. For passengers we see that women, higher income and caste categories are more likely to have some missing information. All our regressions below control for these characteristics to exclude any bias, yet there is obviously still a risk that non-reporting is tight to relevant non-observable characteristics. Not surprisingly, income is the variable where most of the missings occur. In our regressions below we introduce (but do not show) next to the various income categories a category "income not reported". This dummy was in none of the regressions significant, also suggesting that there is no systematic non-reporting in the data.

Moreover, given the importance of gender in our analysis, we analyze men and women separately. Since, we do only have 15 female drivers in our sample. These are not part of a separate analysis. We also have 27 individuals in the sample that reported to be sometimes a driver and sometimes a passenger. They are also excluded from the driver and passenger samples.

Given that road usage behavior, helmet use and speed vary a lot with the distance of a trip, the type of roads used and traffic density, for each user we collected information for up to three different types of trips: trips in the neighborhood, short distance trips (partly outside the neighborhood) and long distance trips. Hence, in the empirical analysis we exploit the variation across different types of trips using single trips as the unit of analysis and clustering standard errors at the individual level.

\section{[insert Table 1 here]}

Table 1 shows some basic descriptive statistics of our sample, separated by drivers and passengers. The average age is 35 years for drivers and 38 years for passengers. Almost all drivers are men, passengers are predominantly female (75\%). Drivers are typically married and are the main bread winners in their household. Among male passengers $69 \%$ reported to be married and $69 \%$ of them contribute to household income. Among female passengers the share married is even at $86 \%$. The education level is relatively high. Almost $50 \%$ of all drivers completed middle or high school. The education level of passengers is significantly lower. The 
religious composition is similar among drivers and passengers and shows that more than $80 \%$ of respondents are Hindus. Muslims and Sikhs represent respectively around $11 \%$ and $3.5 \%$ of the sample. $71 \%$ of the respondents pray daily and $88 \%$ believe that their fate is in god's hands. Finally, less than $15 \%$ of respondents have health insurance.

Before we discuss the specification of our empirical tests, we present three sets of variables in more detail, since they are key in the empirical analysis: (i) helmet use and speed, (ii) measures of risk aversion and (iii) measures of risk awareness and perceptions, insurance coverage, motorbike characteristics and other behavioral patterns beyond helmet use and speed.

\subsection{Helmet use and speed}

Respondents were asked whether they own a helmet and whether they use their helmet for trips in the neighbourhood and for trips on main roads either for short or long distances. ${ }^{6}$ We asked further questions regarding the characteristics of the helmet and its condition. The corresponding descriptive statistics are shown in Table 2, separately for male drivers, passengers (male and female) and all respondents together.

$$
\text { [insert Table 2 here] }
$$

While among drivers 93\% own a helmet, among passengers this share is only around $50 \%$. Maybe surprisingly, there is hardly any difference between male and female passengers, suggesting that not gender, but the fact of being a passenger leads to this low share in helmet ownership. Passengers seem to feel a lower need for helmet use than drivers. However, as will be seen below, female passengers use helmets much less frequently than male passenger despite a similar level of ownership.

Further investigations show that coming from a richer family, being the head of household, being younger, being more risk averse, owning a motorbike and using the motorbike to commute to work are all variables positively correlated with helmet ownership. Finally, and not surprisingly, individuals belonging to the Sikh community are much less likely to have a helmet. It is important to note that a standard helmet is relatively cheap (typically less than USD 20) in particular if compared to the price of the motorbike or the gazoline and

\footnotetext{
${ }^{6}$ Long distance trips were defined in the questionnaire as travels exceeding 15 minutes.
} 
maintenance costs. More precisely, households who own a motorbike in our sample paid on average 45,800 INR (around 1,000 USD) their vehicle and spend each month 1,250 INR (28 USD) in gazoline. Helmets are also easy to find; in Delhi many shops near the main roads sell helmets.

Among drivers, $86 \%$ of all helmets in use are full face helmets. Inspections by our enumerators revealed that in general helmets are in a rather good condition. Only a quarter of all helmets showed some scratches. Only a few helmets were broken and sometimes manually fixed. Almost all helmets had a strap. Passengers, and in particular female passengers, use half-helmets, which obviously offer less protection, much more frequently than drivers.

Helmet use varies significantly across trip circumstances and the three sub-groups of interviewees. The descriptive statistics suggest that both drivers and passengers take into account whether they are traveling a short distance and use side roads or whether they are traveling a longer distance and mainly on main roads. The longer the trip and the bigger the road, the more likely it is that drivers and passengers will wear a helmet. For trips in the neighborhood only $43 \%$ of all drivers and passengers wear a helmet. On long trips the share increases to almost $75 \%$. However, as can be seen in Table 2, the difference between drivers and passengers is substantial at all levels.

The speed at which drivers and passengers travel is derived from the information on time spent on the road and distance traveled. This is more reliable than asking respondents directly. First, drivers might be reluctant to tell the truth if they notoriously exceed the official speed limit, even if it is only weakly enforced. Second, drivers may tend to report maximum rather than average speed. ${ }^{7}$

For drivers we find an average speed of $36 \mathrm{kph}(22.4 \mathrm{mph})$. For passengers the average is slightly lower. Using speed and helmet use we constructed a variable that we call hereafter the level of protection. For this purpose, we code two speed categories (below the male average (36 kph) and above) and two helmet usage categories (wearing and not wearing). This gives four possible combinations, which we rank as follows: "no protection" (no helmet and high speed), "partial protection" (either only helmet or only low speed) and "full protection" (helmet and low speed).

\footnotetext{
${ }^{7}$ We acknowledge that this average speed might to some extent reflect the traffic density. Nonetheless, the small size of engine may allow some drivers to sneak between cars. Moreover, we control for circumstances to some extent.
} 


\subsection{Measure of risk aversion}

The measurement of risk aversion is a well-known challenge. Our survey covered (i) selfreported risk aversion in general and in four specific domains: on the road, in finance, in sports and in health; (ii) lottery questions, (iii) specific risk aversion questions related to finance, such as the amount the respondent would invest in a highly risky business project, to what extent the respondent would gamble with own income and the willingness to pay for lottery tickets with different gains as well as (iv) risk aversion questions related to health, for instance the willingness to take a risky drug that would in the good state allow the respondent to live in good health for the rest of the life and in the bad state lead to premature death.

After exploring these different measures and reviewing the literature, we decided to use the self-reported risk aversion measures, i.e. the respondent's answer to the question whether he or she is taking risks in general and in the four specific domains: on the road, in finance, in sports and in health. We think this choice makes sense in our case, since road accidents typically have financial and health implications. Moreover, driving has, at least for some, features of a sport and hence it is reasonable to take into account this dimension as well. ${ }^{8}$ Hence we calculate the arithmetic mean of the self-rated degree of risk-taking (reported from 1 (risk seeking) to 4 (extremely risk averse)) in general and in these four domains. This variable is thus a continuous variable taking values between 1 and 4 which we call the "Risk aversion score". Our preferred choice is also in line with recent studies in this field. Ding et al. (2010), Dohmen et al. (2011) and Hardeweg et al. (2012) for instance use Chinese, German and Thai data respectively and all find experimental evidence that self-assessed risk aversion measures perform much better than risk aversion measures derived from lottery or hypothetical investment questions. Indeed while lottery choices are useful for predicting behavior regarding risky financial decisions, they appear to be uninformative for behaviors in other domains (see Wölbert and Riedl, 2013). Moreover, context specificity of risk aversion has also been shown by Barseghyan et al. (2011) and Einav et al. (2012). These two studies found that many individuals reveal different degrees of risk aversion in different life domains (such as health, disability and car insurance). ${ }^{9}$ Finally, a further validation of our choice is

\footnotetext{
${ }^{8}$ In a closely related article Bhattacharya et al. (2007) measured the willingness-to-pay to reduce the risk of dying in road accidents in Delhi, which may also be interpreted as a measure of risk aversion, although the authors use it as a measure of the value of a statistical life.

${ }^{9}$ van der Pol and Ruggeri (2008) even show that risk aversion may vary within domains across different situations. With respect to health their findings suggest that individuals are risk averse when immediate death
} 
shown in Table 3, where we report the correlation between the risk aversion score and three health-related risky behaviors: smoking, drinking and heavy drinking. Throughout we find a significant negative correlation, i.e. risk aversion is negatively correlated with smoking and drinking, suggesting that our preferred measure is a reasonable measure of risky behaviors with health implications.

However, since any measure of risk preferences can be subject to debate, we will make use of the richness of our data set and check the robustness of our results with respect to alternative measures, although we do not expect all measures mentioned above to give similar results as some of these measures are clearly less adapted to our context than others.

Moreover, because the literature suggests that answers to questions about risk aversion, health related behavior and safety perceptions may be subject to framing effects, i.e. answers may depend on how and by whom the questions have been asked (see Lutz and Lipps, 2010), we also include in all estimations below interviewer-effects.

$$
\text { [insert Table } 3 \text { here] }
$$

\subsection{Other road use behaviors, safety perceptions and motorbike character- istics}

To get a good sense of the frequency of road usage, respondents were asked to provide the reason for the use of the motorbike. As can be seen in Table $4,82 \%$ of drivers use the motorbike to commute to work. Among passengers this share is only about $40 \%$. Frequency of use by different types of roads was also assessed, for instance whether they use ring roads. A quarter of all drivers usually travel with one or more passengers. $60 \%$ of the passengers state that they travel with at least two other persons on the motorbike, i.e. the driver and at least another passenger, often a child.

$$
\text { [insert Table } 4 \text { here] }
$$

Drivers were also asked to assess their own driving skills and whether they had any type of formal training, either by getting a driving license, taking at least some lessons or some type of exam. While about $91 \%$ report having a licence, only $65 \%$ took an exam and only $42 \%$ report having had driving lessons. $56 \%$ have confidence in their own driving ability (i.e. those is at stake, as in our case, but sometimes risk seeking with regard to other health gambles. 
individuals declare that they have better driving skills than others) and $74 \%$ think that they drive more carefully than the average driver, implying that many underestimate the riskiness of their own behavior. Passengers were asked whether they think their driver should drive more carefully; $64 \%$ of them confirmed.

Finally, we collected information about risk perceptions and own road accident experiences. ${ }^{10}$ For instance, respondents were asked to provide an estimate on the number of road deaths, road injuries and the share of motorcyclists among total road accident fatalities they thought had taken place during the previous year in Delhi. Their answers were then compared to the official figures provided by the National Crime Record Bureau for the year 2010. Hence, for each respondent we could establish whether the respondent underestimated, roughly accurately estimated or overestimated road risks. In what follows, we define underestimation as a lack of awareness. I.e. if someone overestimated the figure, we still consider this person as more aware than someone who underestimates it. So what counts is that someone is aware that at least ' $\mathrm{x}$ ' fatalities occur. Interestingly, about $50 \%$ of the respondents underestimate the incidence of road traffic accident injuries. For fatalities the share is closer to $45 \%$. Among passengers the share of those who underestimate is slightly higher. On average, $7 \%$ of the respondents had already experienced a road traffic accident most of these involving injuries and some fatalities.

For households that owned a motorbike, we also collected information about the motorbike such as size, age, first-hand purchase, frequency of technical checks and insurance. Some of these characteristics are shown in Table 4 . Around $87 \%$ of our sample belong to a household owning a motorbike. Motorbikes are on average rather small (mostly scotters and mopeds). Only $16 \%$ have an engine displacement of more than 150 cubic centimetres. ${ }^{11}$ More than $80 \%$ of the respondents report having insurance for their motorbike.

\section{$5 \quad$ Empirical specifications}

The theoretical considerations made above imply an empirical focus on three aspects: (i) How does risk aversion affect helmet use and speed? (ii) If both can be chosen simultaneously, how are these choices correlated? (iii) How do other socio-demographic and economic char-

\footnotetext{
${ }^{10}$ Dionne et al. (2007) have shown that risk perceptions influence driving behavior.

${ }^{11}$ This figure highlights the difference between motorcyclists in India and the US or Europe.
} 
acteristics as well as behaviors and perceptions influence both helmet use and speed? In our empirical analysis we propose two alternative ways of accounting for the simultaneity of the two decisions: first to combine both choices in one categorial variable (the level of "protection' hereafter) and second to model both choices separately, but to estimate them jointly to account for the possible correlation of the residuals.

The level of protection is coded as follows: "no protection" (no helmet and high speed, $y=1$ ), "partial protection" (either only helmet or only low speed, $y=2$ ) and "full protection" (helmet and low speed, $y=3$ ). To explore the role of risk aversion and other factors on the chosen level of protection, we estimate an ordered logit model, which can be described as follows.

The cumulative probability $C_{i j}$ gives the probability that the $i$ th individual is in the $j$ th or higher category:

$$
C_{i j}=\operatorname{Pr}\left(y_{i} \leq j\right)=\sum_{c a t=1}^{j} \operatorname{Pr}\left(y_{i}=k\right) .
$$

This cumulative probability can be turned into the cumulative logit:

$$
\operatorname{logit}\left(C_{i j}\right)=\log \left(\frac{C_{i j}}{1-C_{i j}}\right)
$$

The ordered logit model represents the cumulative logit as a linear function of exogenous variables $x_{i}$ :

$$
\operatorname{logit}\left(C_{i j}\right)=a_{j}-x_{i}^{\prime} \beta_{p}
$$

where $a_{j}$ indicates the logit of the odds of being equal to or less than category $j$ for the 'baseline' group, i.e. when all $x_{i}$ are zero. Hence, these intercepts, or 'cut-points', increase over $j$. The coefficients $\beta_{p}$ tell us how an increase in $x_{i}$ increases the log-odds of being higher than category $j$. It is assumed that the effect of $x_{i}$, i.e. $\beta_{p}$ does not vary with the cut-point considered. Put differently, the marginal effect of risk aversion on the chosen protection level for instance, does not vary whether a given individual has currently no or partial protection.

Again the second approach we use consists of unpacking the level of protection, and hence considering two functions one for helmet use, $h_{i}$ and one for speed, $s_{i}$, but to estimate them simultaneously. Helmet adoption is used in a binary form, i.e. the driver wears a helmet 
$(h=1)$ or not $(h=0)$. Hence we use a simple probit model for estimation. Speed is measured continuously (in kph) and we thus use a linear regression model.

$$
\begin{gathered}
\operatorname{Probit}\left(h_{i}=1 \mid x_{i}\right)=\theta\left(x_{i}^{\prime} \beta_{h}+\epsilon_{h i}\right), \\
s_{i}=\beta_{s 0}+x_{i}^{\prime} \beta_{s 1}+\epsilon_{s i} .
\end{gathered}
$$

We jointly estimate Equations (18) and (19) with full maximum likelihood, assuming that the errors, $\epsilon_{s i}$ and $\epsilon_{h i}$, follow a bivariate normal distribution, and then test the covariance of the error terms. ${ }^{12}$ In the absence of convincing instruments we exclude speed from the helmet equation and helmet use from the speed equation.

Again, for passengers we assume that only helmet use is a choice, which we model with a simple probit model as described in Equation (18).

\section{$6 \quad$ Empirical analysis and results}

\subsection{Drivers}

\subsubsection{The chosen level of protection and the role of risk aversion}

The results of the ordered logit model are shown in Table 5. We start with a model in which the only explanatory variable is risk aversion (col. (1)), then we introduce successively socio-demographic and economic characteristics (col. (2)), religion (col. (3)) and driving behavior and attitudes towards road safety issues (col. (4)). Augmenting the model step-bystep allows us to see whether the estimated effects are sensitive to the inclusion and exclusion of particular variables. As mentioned above, we also include here and in all estimations that follow interviewer-effects.

Risk aversion has throughout a positive effect on protection, but is statistically only significant if the full set of explanatory variables is included (col. (4)). Moreover the size of the coefficient is also sensitive to the exact sample chosen. Risk aversion is significant in column (5) which uses the same sample as column (4), but does not control for driving behavior and safety perception. ${ }^{13}$ Overall, the effect of risk aversion is thus in line with the

\footnotetext{
${ }^{12}$ For estimation we use the STATA module 'cmp' developed by Roodman (2011), which can deal with conditional mixed process models.

${ }^{13}$ When we include variables that measure driving behavior and safety perceptions, we loose 116 observations
} 
prediction in the model. In quantitative terms the estimated coefficient implies that at the sample mean an increase by one standard deviation in the risk aversion score $(+0.82$ or $29 \%)$ increases the probability that a driver will choose full protection by almost eight percentage points (marginal effects are shown in the appendix). If we use risk aversion in each of the four domains constituting our index, we find qualitatively the same effects. If we use other measures such as the lottery questions and so on, we find either similar or insignificant results; only for the questions regarding risk-taking behavior in business projects does the coefficient have a significant opposite effect, but we do not consider this risk dimension as being very relevant here (results not shown in Table).

Among the socio-demographic characteristics, it is interesting to see that the number of children is positively associated with the level of protection. This may imply that drivers that feel a responsibility towards a family choose a higher level of protection. Every additional child increases the probability that the driver chooses full protection by seven to eight percentage points (the effect is probably non-linear, as household size has a negative effect). Literacy is also associated with a higher level of protection. Illiterate drivers have an approximate 25 percentage point lower probability of adopting the full protection compared to literate drivers. The estimated income effects suggest that poorer individuals choose lower levels of protection compared to richer individuals - in particular very rich individuals. Drivers with a reported monthly household income of 25,000 INR and above (420 USD and more) have a probability that is higher by 20 to 25 percentage points of choosing full protection compared to drivers with a reported household income of less than 5,000 INR. In the middle income range, the income gradient is almost flat.

Muslims relative to Hindus choose lower levels of protection, although the coefficient is not significant throughout. The effects associated with the Sikh group are not significant, although we have seen above that they show significantly lower levels of helmet use. As we will see below, they also choose lower speed levels and hence the adverse effect of no helmet use on protection is mitigated. We do not find, as one could expect, that those drivers who think that their fate is in god's hands choose lower levels of protection.

There is no difference between drivers that have already experienced an accident and those who have not. We only find that drivers who never use ring roads choose higher levels due to missing information. 
of protection. As can be seen below, this has mainly to do with the lower speed chosen. The choice of the road might even be part of the safety strategy: drivers decide to avoid ring roads in order to travel at a lower speed, implying that "roads used" might be an endogenous decision variable. The effect associated with health insurance is also interesting. We do not find any evidence of moral hazard: insured people are more likely, not less, to choose high levels of protection. Finally, as already seen in our descriptive table above, drivers tend to chose higher protection on long distance trips and lower protection on short distance trips. For a long distance trip the probability of choosing full protection compared to a short distance trip is about 15 percentage points higher.

[insert Table 5 here]

\subsubsection{Unpacking protection: the choice of speed and helmet use}

We now decompose the protection level adopted by the driver and consider the multidimensional aspect of this behavior by looking at the exact strategy a driver opts for. We thus investigate the relation between helmet use and average speed using the simultaneous equations system described above. Here again, we successively expand the list of explanatory variables. Using a longer list of variables again implies working with a slightly smaller sample. In all specifications we control for interviewer-effects.

Risk aversion is positively associated with helmet use. This effect is relatively robust. At the sample mean, a one standard deviation increase in the risk aversion measure (i.e. by 0.82 points or $29 \%$ ) increases the probability of helmet use by roughly 3 percentage points. However, risk aversion does not have a significant impact on speed. This is coherent with the predictions of our theoretical model. Risk averse individuals engage in self-insurance, but the effect on self-protection is ambiguous. These results also largely hold if we estimate separately by the type of trip. They are also confirmed if we take risk-taking behavior in each domain alone. If we take the other risk-measures in our data set we find insignificant results except for one of the lottery-based measures and the measure based on the risky medicine question for which risk-aversion seems to lower the probability of helmet use (results not shown in Table). Again, we trust our self-reported risk measures more. We also obtain absolutely coherent results if, instead of the binary helmet variable, we use the combined helmet and strap use 
( 5 categories, see Table 2 ). The effects of the other explanatory variables are largely in line with our findings in Table 5, where we analyzed protection, i.e. helmet and speed combined. Helmet use is lower among the illiterate population, between 10 to 12 percentage points depending on the specification. Tertiary education seems to further increase the probability of helmet use, but this effect loses significance if religiousness and social status is added to the list of regressors. Sikhs are, for the reasons given above, less likely to wear a helmet (17 to 20 percentage points less likely), but they also drive on average slower ( 8 to $10 \mathrm{kph}$ less (4 to $6 \mathrm{mph})$ ) and thus seem to compensate their increased exposure to risk. For that group, not wearing a helmet is not necessarily the preferred choice, but rather a (religious) constraint and hence risk compensation can be a rational response. The more children a driver has the lower the chosen speed level (roughly $3 \mathrm{kph}(1.9 \mathrm{mph})$ less per child), however, more children is not associated with a higher probability of helmet use. Income also does not correlate with helmet use conditional on all other included variables, however it plays a role for speed. The results suggest that speed first increases and then decreases with income. Drivers with a monthly household income of more than 25,000 INR drive on average 15 to $25 \mathrm{kph}$ (9 to 16 $\mathrm{mph}$ ) slower than drivers with a monthly household income of 10,000 to 15,000 INR. Here it is important to note that the size of the motorbike is controlled (engine displacement).

Among the variables measuring driving behavior and safety perceptions, a few effects stand out. Drivers who use their motorbike regularly to commute to work are more likely to wear a helmet $(+6$ percentage points). There is no effect on speed. Risk awareness seems to matter: drivers who took driving lessons are more likely to wear a helmet $(+7$ percentage points). Interestingly, individuals who have a driving license but did not take driving lessons are not more likely to use a helmet than those who don't have a license at all (effect not shown in Table 6). Again, this suggests that it is awareness that matters. Drivers who underestimate the annual number of road traffic accident injuries, and thus the implied risk more generally, are less likely to wear a helmet. More passengers on the motorbike is also associated with lower helmet use. Remarkably, drivers with health insurance are more likely to wear a helmet and to drive slower. Note that this result holds even if we control for income, education and a whole range of other characteristics.

Finally, since we estimate helmet use and the choice of speed with a simultaneous equation system, it is interesting to examine the correlation between the error terms of both equations. 
The error terms capture those determinants that are not included in the list of regressors and of course measurement error. If we control only for risk aversion (col. (1)), the error terms are significantly negatively correlated, implying that the net effect of the unobserved or not included factors tends to increase helmet use and to lower speed, or, in turn to decrease helmet use and to increase speed. As more and more explanatory variables are included (col. (2) and col. (3)), we see that the correlation remains significantly negative and even increases in absolute size. If we include those variables that account for driving behavior and safety perceptions (col. (4)), we see that the correlation coefficient loses its significance. This is not due to the reduced sample size, as col. (5) shows, where we re-estimate the regression on the same sample without controlling for driving behavior and safety perceptions. As discussed above, among the variables measuring driving behavior and safety perceptions, of particular significance in both equations are those that can be related to risk awareness, such as taking driving lessons, underestimating the number of annual fatalities and having an insurance. Put differently, given that we control (even if imperfectly) for risk aversion and a large set of socio-demographic and economic characteristics including religiousness, we believe that risk awareness is a major determinant that can explain whether individuals wear a helmet and drive slowly or do not wear a helmet and drive fast. Hence, whereas risk aversion motivates drivers to compensate for higher speed through a higher propensity to use a helmet, a lack of awareness comes with both, high speed and no helmet, i.e. both decisions seem to complement each other. All our results are qualitatively not different if we limit the sample to those drivers that own a helmet (not shown in Table).

$$
\text { [insert Table } 6 \text { here] }
$$

\subsection{Passengers}

Again, for passengers we assume that they only make a choice regarding helmet use and consider speed to be determined by the driver, although there might be possibilities for the passenger to influence the driver to some extent. This is discussed in more detail below. Table 7 shows the results. We only present marginal effects.

[insert Table 7 here] 
Interestingly, for passengers we do not find any significant effect for risk aversion if we use our risk aversion score. However, we do find some significant positive effects when using the risky medicine question; nevertheless, for other risk aversion measures, in particular lottery questions, again the effects are negative (results not shown in Table), so no clear-cut conclusion can be drawn for passengers.

One of the most important determinants of helmet use among passengers is gender. Men are between 25 to 40 percentage points more likely to wear a helmet than women, controlling for all other socio-demographic and economic characteristics and differences in travel habits and safety perceptions. Some of the factors driving this result have already been discussed above. Women are exempted from the helmet law. Moreover, women may refuse to wear a helmet because of their hair-dress. Nevertheless according to our data (cf. Table 2), 45\% of all women always wear a helmet at least on long trips. On short trips this share is still at $15 \%$. We also test whether owning a helmet makes a difference, even though this variable is of course highly endogenous. Owning a helmet increases the probability of wearing a helmet by about 30 percentage points. The gender effect is strongly reduced in the specification with helmet ownership.However, given the low cost of and easy access to helmets, we believe that there is no difference in modelling the decision to use and the decision to buy a helmet.

Religiousness and whether a passenger believes that life is in the hands of a superior force does not explain helmet use. Although the coefficient associated with the latter variable is negative throughout, it is never statistically significant. Education and income also seem to play no role. The same is true for marital status, having children and household size. However, being of a lower caste decreases helmet use, by 8 to 15 percentage points.

Based on the predictions derived from our theoretical model, we expect a negative correlation between helmet use and exogenous improvements in the safety level (the "Peltzmaneffect"). In Table 7 we do indeed see that the passenger's choice to wear a helmet is influenced by the driver's choice of speed. Helmet use increase with speed, at least if a speed below 20 $\mathrm{kph}$ is compared to a speed between 20 and $40 \mathrm{kph}$ (12 and $25 \mathrm{mph}$ ).

As with drivers, we again find that people who underestimate the risk of a road traffic accident wear a helmet less often (10 to 15 percentage points less likely). Surprisingly, for passengers, in contrast to drivers, we find that passengers with health insurance wear a helmet less often (12 percentage points less likely). It could be that for passengers there is some moral 
hazard, in a sense that passengers think better health care reduces the cost of an injury, but this is a strong hypothesis that needs further empirical testing. Finally, we see that passengers who think their driver is speeding too much and who hence may urge their driver to pay more attention, wear a helmet less often (9 to 12 percentage points less likely). This may imply that passengers try to reduce the probability of accident involvement by influencing the driver's chosen level of speed. This result can also be seen as evidence of a 'Peltzman effect' as it reflects a trade-off between the passenger's and driver's safety efforts.

\section{Conclusion}

Risky health behavior is in many domains still only poorly understood. The analysis is often plagued by incomplete data and a general lack of information. In this study, we try to understand the behavior of helmet use among motorcycle riders and passengers in Delhi, a context in which road safety is low and helmet use is far from being the norm. We use a very detailed data set collected exactly for the purpose of that study. To guide our empirical analysis, we rely on a simple model in which drivers decide on their speed and helmet use. While a helmet provides insurance if an accident happens, speed affects the probability that an accident will occur. However, a lower speed implies time costs and helmet use comes with a level of discomfort that has to be borne by the user. Key variables in our analysis are risk aversion as well as aspects related to risk awareness.

The empirical findings suggest that risk averse drivers are more likely to wear a helmet. A one standard deviation increase in our risk aversion score (i.e. by $29 \%$ ) increases the probability of using a helmet on a given trip by 3 percentage points. This is certainly not a very strong effect, but cumulated over many trips it means a substantial reduction in the risk of being seriously injured in the event of an accident. We do not find any systematic effect of risk aversion on speed. Both results are coherent with our theoretical model. Interestingly, helmet use also increases with education: illiterate drivers are by about $10 \%$ less likely to wear a helmet than literate drivers. Tertiary education further increases helmet use. Speed decreases with the number of children at home suggesting that family responsibilities stimulate

drivers to take fewer risks. Speed first increases and then decreases with income, i.e. the middle class drives the fastest.

Drivers who show a higher awareness of road risks, because, for instance, they are more 
conscious about the health risks faced when traveling on Delhi's roads or have taken driving lessons, are both more likely to wear a helmet and to speed less. In turn, those drivers who show a high level of unawareness take the highest risks. Controlling for risk awareness, we observe that drivers tend to compensate between speed and helmet use: the Sikh who cannot wear a helmet because of the turban, drive, on average, slower.

For passengers, we find a similar pattern. Their probability of helmet use increases with the driver's chosen level of speed. The fact that generally passengers less often wear a helmet than drivers, and women less often than men, even controlling for helmet ownership, suggests that norms and habits also play an important role. Breaking these is one of the major challenges that needs to be overcome.

The most obvious solution to India's road safety problem and the related high social costs that result from it, is to enforce the helmet law and speed limits and hence to ignore the associated private costs such as time costs and discomfort. An alternative strategy, and probably more feasible in the current context, is to design interventions which raise awareness of road risks. In terms of our model, this means bringing the expected probability of an accident at a given speed and the expected gain of helmet use closer to its actual levels. Improvements to the road infrastructure such as separate lanes for cars and motorbikes are also a possible solution, but, as our analysis and a few other examples in the literature show, these measures bear the risk that drivers will react by increasing speed or lowering helmet use.

We end our analysis with a word of caution. In this study we work with purely observational data and hence we cannot really claim to tease out causal relationships. However, given the detail of the information we have, we think there are good reasons to believe that biases due to omitted variables are relatively limited. Further research should try to validate some of the findings we generated through an adequate experimental design. Nevertheless, we believe that our analysis is a first important step in understanding helmet use in a low-income but highly-motorized context. 


\title{
Appendix
}

\section{Determinants of non-reporting}

\author{
[insert Table A1 here]
}

\section{Marginal effects}

$$
\text { [insert Tables A2 and A3 here] }
$$

\section{Acknowledgements}

We thank SIGMA Research and Consulting for excellent collaboration in the field. We are also grateful to Arjun Bedi, Denis Cogneau, Pierre-Yves Geoffard, Robert Sparrow, Lara Tobin, Armando Treibich and Rafael Treibich for very valuable comments on this version. Thanks are also due to seminar participants at Linz University, Erasmus University Rotterdam, Passau University, Université Paris Dauphine, the Paris School of Economics and the Aix-Marseille School of Economics and participants of the Development Economics Conference of the German Economic Association in Munich and of the "Research in Health and Labour" TEPP Conference in Le Mans. Financial support for this research from the Health Chair - a joint initiative by PSL, Université Paris-Dauphine, ENSAE and MGEN under the aegis of the Fondation du Risque (FDR) - the Paris School of Economics Research Fund and the International Institute of Social Studies of Erasmus University Rotterdam is gratefully acknowledged.

\section{References}

Levon Barseghyan, Jeffrey Prince, and Joshua C. Teitelbaum. Are risk preferences stable across contexts? evidence from insurance data. American Economic Review, 101(2):591$631,2011$.

Soma Bhattacharya, Anna Alberini, and Maureen L. Cropper. The value of mortality risk reductions in delhi, india. Journal of Risk and Uncertainty, 34:21-47, 2007. 
Glenn Blomquist. A utility maximization model of driver traffic safety behavior. Accident Analysis and Prevention, 18(5):371-375, October 1986.

Eric Bryis and Harris Schlesinger. Risk aversion and the propensities for self-insurance and self-protection. Southern Economic Journal, 57(2):458-467, October 1990.

Robert S. Chirinko and Edward P. Harper Jr. Buckle up or slow down? new estimates of offsetting behavior and their implications for automobile safety regulation. Journal of Policy Analysis and Management, 12(2):270-296, 1993.

Thomas S. Dee. Motorcycle helmets and traffic safety. Journal of Health Economics, 28: 398-412, 2009.

Xiaohao Ding, Joop Hartog, and Yuze Sun. Can we measure individual risk attitudes in a survey? IZA Discussion Paper Series 4807, Bonn, March 2010.

Georges Dionne and Louis Eeckhoudt. Self-insurance, self-protection and increased risk aversion. Economic Letters, 17(1-2):39-42, 1985.

Georges Dionne, Claude Fluet, and Denise Desjardins. Predicted risk perception and risktaking behavior: The case of impaired driving. Journal of Risk and Uncertainty, 35:237-264, 2007.

Thomas Dohmen, Armin Falk, David Huffman, Uwe Sunde, Jürgen Schupp, and Gert G. Wagner. Individual risk attitudes: Measure, determinants, and behavioral consequences. Journal of the European Economic Association, 9(3):522-550, June 2011.

Isaac Ehrlich and Gary S. Becker. Market insurance, self-insurance and self-protection. Journal of Political Economy, 80:623-648, 1972.

Liran Einav, Amy Finkelstein, Iuliana Pascu, and Mark R. Cullen. How general are risk preferences? choices under uncertainty in different domains. American Economic Review, 102(6):2606-2538, 2012.

Michael T. French, Gulcin Gumus, and Jenny F. Homer. Public policies and motorcycle safety. Journal of Health Economics, 28:831-838, 2009. 
Jonathan P. Goldstein. Self-insurance: The case of motorcycle helmets. The Journal of Risk and Insurance, 63(2):313-322, June 1996.

Michael Grimm and Carole Treibich. Determinants of road traffic crash fatalities across indian states. Health Economics, 22(8):915-930, August 2013.

Bernd Hardeweg, Lukas Menkhoff, and Hermann Waibel. Experimental validated survey evidence on individual risk attitudes in rural thailand. Discussion Paper No 464, April 2012.

Arvind Kumar, Sanjeev Lalwani, Deepak Agrawal, Ravi Rautji, and TD. Dogra. Fatal road traffic accidents and their relationship with head injuries: An epidemiological survey of five years. Indian Journal of Neurotrauma, 5(2):63-67, 2008.

Kangoh Lee. Risk aversion and self-insurance-cum-protection. Journal of Risk and Uncertainty, 17:139-150, 1998.

BC. Liu, R. Ivers, R. Norton, S. Boufous, S. Blows, and SK. Lo. Helmets for preventing injury in motorcycle riders. Cochrane Database of Systematic Reviews, 1, 2008.

Alan D. Lopez, Colin D. Mather, Majid Ezzati, Dean T. Jamison, and Christopher JL. Murray. Global and regional burden of disease and risk factors, 2001: systematic analysis of population health data. The Lancet, 367(9524):1747-1757, May 2006.

Adrian K. Lund and Brian O'Neill. Perceived risks and driving behavior. Accident Analysis and Prevention, 18(5):367-370, 1986.

Adrian K. Lund and Paul Zador. Mandatory belt use and driver risk taking. Risk Analysis, 4(1):41-53, 1984.

Georg Lutz and Oliver Lipps. How answers on political attitudes are shaped by interviewers: Evidence from a panel survey. Swiss Sociological Review, 36(2):345-358, 2010.

Patrick McCarthy and Wayne K. Talley. Evidence on risk compensation and safety behaviour. Economic Letters, 62:91-96, 1999. 
Antoine Messiah, Aymery Constant, Benjamin Contrand, Marie-Line Felonneau, and Lagarde Emmanuel. Risk compensation: A male phenomenon? results from a controlled intervention trial promoting helmet use among cyclists. American Journal of Public Health, 102: S204-S206, 2012.

Dinesh Mohan. Social cost of road traffic crashes in india. In Proceedings First Safe Community Conference on Cost of Injury, pages 33-38, October 2002.

Sam Peltzman. The effects of automobile safety regulation. Journal of Political Economy, 83 (4):677-726, August 1975.

Steven Peterson, George Hoffer, and Edward Millner. Are drivers of air-bag-equipped cars more agressive? a test of the offsetting behavior hypothesis. Journal of Law and Economics, 38(2):251-264, October 1995.

John W. Pratt. Risk aversion in the small and in the large. Econometrica, 32(1/2):122-136, January-April 1964.

David Roodman. Fitting fully observed recursive mixed-process models with cmp. Stata Journal, 11(2):159-206, 2011.

Russel S. Sobel and Todd M. Nesbit. Automobile safety regulation and the incentive to drive recklessly: Evidence from nascar. Southern Economic Journal, 74(1):71-84, July 2007.

Adam Stetzer and David A. Hofmann. Risk compensation: Implications for safety interventions. Organizational Behavior and Human Decision Processes, 66(1):73-88, April 1996.

Marjon van der Pol and Matteo Ruggeri. Is risk attitude outcome specific within the health domain? Journal of Health Economics, 27:706-717, 2008.

WHO. World report on road traffic injury prevention. Technical report, World Health Organization, 2004.

WHO. Helmets: a road safety manual for decision-makers and practitioners. Technical report, World Health Organization, 2006.

WHO. Global status report on road safety. Technical report, World Health organization, 2009. 
Gerald J. S. Wilde. The theory of risk homeostasis: Implications for safety and health. Risk Analysis, 2(4):209-225, 1982.

Eva Wölbert and Arno Riedl. Measuring time and risk preferences: Reliability, stability, domain specificity. CESifo Working Paper 4339, Munich, July 2013. 


\section{Tables}

Table 1: Socio-demographic characteristics of drivers and passengers

\begin{tabular}{|c|c|c|c|c|}
\hline \multirow[b]{2}{*}{$(\%)$} & \multirow{2}{*}{$\begin{array}{c}\text { Male } \\
\text { drivers }\end{array}$} & \multicolumn{2}{|c|}{ Passengers } & \multirow{2}{*}{$\begin{array}{c}\text { All } \\
\text { respondents }\end{array}$} \\
\hline & & Male & Female & \\
\hline Male & - & - & - & 67.41 \\
\hline \multicolumn{5}{|l|}{ Age distribution } \\
\hline 15-29 years & 37.83 & 32.26 & 27.70 & 34.92 \\
\hline 30-39 years & 25.36 & 13.98 & 32.37 & 26.05 \\
\hline 40-49 years & 20.25 & 15.05 & 25.18 & 20.84 \\
\hline $50-59$ years & 11.25 & 17.20 & 8.99 & 10.98 \\
\hline 60 years and above & 5.32 & 21.51 & 5.76 & 7.21 \\
\hline Average (in years) & 35.44 & 42.10 & 37.00 & 36.47 \\
\hline Married & 69.34 & 68.82 & 85.56 & 73.39 \\
\hline Contributes to $\mathrm{HH}$ income & 80.78 & 68.78 & 5.80 & 55.00 \\
\hline \multicolumn{5}{|l|}{ Share of the contribution } \\
\hline less than $40 \%$ & 32.09 & 44.09 & 96.01 & 54.59 \\
\hline between $40 \%$ and $60 \%$ & 19.67 & 22.58 & 3.62 & 14.77 \\
\hline more than $60 \%$ & 48.24 & 33.33 & 0.36 & 30.65 \\
\hline \multicolumn{5}{|l|}{ Education level } \\
\hline illiterate & 2.49 & 7.53 & 14.75 & 6.95 \\
\hline primary school & 3.53 & 11.83 & 4.73 & 4.93 \\
\hline secondary school & 48.55 & 65.59 & 49.09 & 50.34 \\
\hline tertiary education & 45.44 & 15.05 & 30.94 & 37.78 \\
\hline \multicolumn{5}{|l|}{ Religion } \\
\hline Hindu & 83.44 & 86.02 & 86.69 & 84.37 \\
\hline Muslim & 12.07 & 10.75 & 9.35 & 11.09 \\
\hline Sikh & 1.23 & 2.15 & 3.24 & 3.44 \\
\hline other & 3.27 & 1.08 & 0.72 & 1.11 \\
\hline Prays daily & 65.30 & 74.19 & 80.73 & 71.24 \\
\hline Believes fate is in god's hands & 87.50 & 90.22 & 87.27 & 88.18 \\
\hline Has health insurance & 15.11 & 11.83 & 12.64 & 13.77 \\
\hline Observations & 489 & 93 & 278 & 902 \\
\hline
\end{tabular}

Notes: The group "all respondents" includes 27 individuals that declared to be sometimes driver and sometimes passenger as well as 15 female drivers. Both groups are not included in any of the sub-samples. 
Table 2: Helmet use and other safety behaviors by type of user and gender

\begin{tabular}{|c|c|c|c|c|}
\hline & \multirow{2}{*}{$\begin{array}{c}\text { Male } \\
\text { drivers }\end{array}$} & \multicolumn{2}{|c|}{ Passengers } & \multirow{2}{*}{$\begin{array}{c}\text { All } \\
\text { respondents }\end{array}$} \\
\hline & & Male & Female & \\
\hline \multicolumn{5}{|c|}{ HELMET CHARACTERISTICS (\%) } \\
\hline \multicolumn{5}{|c|}{ Helmet ownership } \\
\hline yes & 93.24 & 51.61 & 56.20 & 76.92 \\
\hline Observations & 488 & 93 & 274 & 897 \\
\hline \multicolumn{5}{|l|}{ Type of helmet } \\
\hline full face helmet & 86.49 & 82.98 & 65.77 & 80.68 \\
\hline open face helmet & 6.08 & 2.13 & 6.04 & 6.09 \\
\hline half helmet & 6.98 & 14.89 & 27.52 & 12.78 \\
\hline building site helmet & 0.45 & 0 & 0.67 & 0.45 \\
\hline \multicolumn{5}{|l|}{ Condition of the helmet } \\
\hline good condition & 72.93 & 74.47 & 79.33 & 74.59 \\
\hline some scratches & 25.95 & 25.53 & 20.00 & 24.22 \\
\hline broken but manually fixed & 1.12 & 0 & 0.67 & 1.18 \\
\hline \multicolumn{5}{|l|}{ Helmet with strap } \\
\hline yes & 97.75 & 93.75 & 93.42 & 96.49 \\
\hline Observations & 447 & 47 & 152 & 684 \\
\hline \multicolumn{5}{|l|}{ HELMET USE (\%) } \\
\hline \multicolumn{5}{|l|}{ In neighbourhoods } \\
\hline yes & 73.80 & 48.91 & 20.15 & 54.41 \\
\hline \multicolumn{5}{|c|}{ For short trips on main roads } \\
\hline & 79.84 & 48.39 & 30.97 & 60.97 \\
\hline \multicolumn{5}{|c|}{ For long trips on main roads } \\
\hline yes & 96.88 & 83.87 & 52.08 & 81.14 \\
\hline Observations & 481 & 93 & 268 & 884 \\
\hline \multicolumn{5}{|c|}{ OTHER SAFETY BEHAVIORS } \\
\hline average & 36.67 & 30.64 & 29.58 & 33.83 \\
\hline variance & 21.56 & 17.47 & 17.28 & 20.53 \\
\hline Observations & 410 & 73 & 170 & 686 \\
\hline
\end{tabular}

Notes: The group "all respondents" includes 27 individuals that declared to be sometimes driver and sometimes passenger as well as 15 female drivers. Both groups are not included in any of the sub-samples. a) observations with a declared speed of more than $150 \mathrm{kph}$ are excluded. 
Table 3: Probability of engaging in risky health behaviors, linear probability model

\begin{tabular}{lccc}
\hline & Smoking & Drinking & Drinking heavily \\
\hline Risk aversion score & $-0.036^{\star \star}$ & $-0.035^{\star \star}$ & $-0.024^{\star \star}$ \\
& $(0.016)$ & $(0.014)$ & $(0.12)$ \\
Interviewer fixed effects & yes & yes & yes \\
\hline $\mathrm{R}^{2}$ & 0.275 & 0.195 & 0.245 \\
Observations & 832 & 807 & 806
\end{tabular}

Notes: ${ }^{\star} \mathrm{p}<0.10,{ }^{\star \star} \mathrm{p}<0.05,{ }^{\star \star \star} \mathrm{p}<0.01$. Sample of all respondents.

OLS estimations. Robust standard errors are reported in parentheses.

a) had three alcoholic beverages in a row at least once in the past two weeks. 
Table 4: Driving behaviors and risk awareness

\begin{tabular}{|c|c|c|c|c|}
\hline & \multirow{2}{*}{$\begin{array}{l}\text { Male } \\
\text { drivers }\end{array}$} & \multicolumn{2}{|c|}{ Passengers } & \multirow{2}{*}{$\begin{array}{c}\text { All } \\
\text { respondents }\end{array}$} \\
\hline & & Male & Female & \\
\hline \multicolumn{5}{|l|}{ DRIVING BEHAVIORS (\%) } \\
\hline \multicolumn{5}{|l|}{ Road exposure } \\
\hline Uses motorbike to commute $(=1)$ & 83.37 & 67.74 & 29.96 & 76.92 \\
\hline Never uses ring roads $(=1)$ & 12.92 & 16.09 & 24.23 & 16.53 \\
\hline Observations & 487 & 93 & 277 & 897 \\
\hline \# of persons on motorbike & 1.42 & 2.46 & 2.72 & 1.95 \\
\hline Observations & 478 & 87 & 267 & 869 \\
\hline \multicolumn{5}{|l|}{ Driving skills } \\
\hline Confident in own driving ability $(=1)$ & 55.94 & & & \\
\hline Reports driving more carefully than others $(=1)$ & 74.18 & & & \\
\hline \multicolumn{5}{|l|}{ Formal training } \\
\hline Has a driving licence $(=1)$ & 91.45 & & & \\
\hline Took driving lessons $(=1)$ & 42.36 & & & \\
\hline Took a driving exam $(=1)$ & 65.44 & & & \\
\hline Observations & 488 & & & \\
\hline Says own driver should pay more attention $(=1)$ & & 56.06 & 67.00 & \\
\hline Observations & & 66 & 200 & \\
\hline \multicolumn{5}{|l|}{ SAFETY PERCEPTIONS (\%) } \\
\hline Experienced road trafic accident $(=1)$ & 9.67 & 8.79 & 2.17 & 7.15 \\
\hline Observations & 486 & 91 & 277 & 895 \\
\hline \multicolumn{5}{|l|}{ Awareness } \\
\hline Underest. Annual road injuries $(=1)$ & 50.06 & 60.81 & 55.05 & 53.45 \\
\hline Underest. Annual road deaths $(=1)$ & 42.76 & 49.35 & 41.18 & 43.43 \\
\hline Observations & 442 & 77 & 221 & 769 \\
\hline \multicolumn{5}{|l|}{ MOTORBIKE CHARACTERISTICS (\%) } \\
\hline HH owns a motorbike $(=1)$ & 92.62 & 48.39 & 90.65 & 87.35 \\
\hline Observations & 488 & 93 & 278 & 901 \\
\hline \multicolumn{5}{|l|}{ Size of the motorbike } \\
\hline Less than $100 \mathrm{cc}$ & 28.07 & 30.00 & 32.58 & 29.45 \\
\hline Between $100 \mathrm{cc}$ and $150 \mathrm{cc}$ & 54.52 & 57.50 & 53.39 & 54.52 \\
\hline Above $150 \mathrm{cc}$ & 17.40 & 12.50 & 14.03 & 16.03 \\
\hline Observations & 431 & 40 & 221 & 730 \\
\hline Has motorbike insurance $(=1)$ & 80.96 & 85.71 & 82.25 & 81.61 \\
\hline Observations & 436 & 42 & 231 & 745 \\
\hline
\end{tabular}

Notes: The group "all respondents" includes 27 individuals that declared to be sometimes driver and sometimes passenger as well as 15 female drivers. Both groups are not included in any of the sub-samples. 
Table 5: Determinants of level of protection chosen by drivers, ordered logit specification, coefficients

\begin{tabular}{|c|c|c|c|c|c|}
\hline & $(1)$ & $(2)$ & $(3)$ & $(4)$ & $(5)$ \\
\hline Risk aversion score & $\begin{array}{r}0.244 \\
(0.163)\end{array}$ & $\begin{array}{r}0.229 \\
(0.174)\end{array}$ & $\begin{array}{r}0.274 \\
(0.175)\end{array}$ & $\begin{array}{c}0.386^{\star \star} \\
(0.197)\end{array}$ & $\begin{array}{c}0.411^{\star \star} \\
(0.189)\end{array}$ \\
\hline \multicolumn{6}{|l|}{ Socio-demographic characteristics } \\
\hline Age (in years) & & $\begin{array}{r}0.008 \\
(0.012)\end{array}$ & $\begin{array}{r}0.006 \\
(0.012)\end{array}$ & $\begin{array}{r}0.006 \\
(0.014)\end{array}$ & $\begin{array}{r}0.002 \\
(0.013)\end{array}$ \\
\hline Married $(=1)$ & & $\begin{array}{r}-0.422 \\
(0.331)\end{array}$ & $\begin{array}{r}-0.464 \\
(0.340)\end{array}$ & $\begin{array}{r}-0.263 \\
(0.375)\end{array}$ & $\begin{array}{r}-0.314 \\
(0.370)\end{array}$ \\
\hline Number of children & & $\begin{array}{c}0.276^{\star \star} \\
(0.120)\end{array}$ & $\begin{array}{c}0.292^{\star \star} \\
(0.122)\end{array}$ & $\begin{array}{l}0.321^{\star \star} \\
(0.130)\end{array}$ & $\begin{array}{l}0.355^{\star \star \star} \\
(0.133)\end{array}$ \\
\hline Household head $(=1)$ & & $\begin{array}{r}-0.354 \\
(0.325)\end{array}$ & $\begin{array}{r}-0.357 \\
(0.328)\end{array}$ & $\begin{array}{r}-0.583 \\
(0.378)\end{array}$ & $\begin{array}{r}-0.612 \\
(0.375)\end{array}$ \\
\hline Household size & & $\begin{array}{c}-0.102^{\star} \\
(0.055)\end{array}$ & $\begin{array}{r}-0.090 \\
(0.055)\end{array}$ & $\begin{array}{c}-0.111^{\star} \\
(0.059)\end{array}$ & $\begin{array}{l}-0.117^{\star \star} \\
(0.057)\end{array}$ \\
\hline \multicolumn{6}{|l|}{ Education ref: Primary-secondary education } \\
\hline Illiterate & & $\begin{array}{c}-1.195^{\star} \\
(0.614)\end{array}$ & $\begin{array}{c}-1.076^{\star} \\
(0.646)\end{array}$ & $\begin{array}{r}-0.959 \\
(0.675)\end{array}$ & $\begin{array}{c}-1.141^{\star} \\
(0.622)\end{array}$ \\
\hline Tertiary education & & $\begin{array}{r}0.251 \\
(0.209)\end{array}$ & $\begin{array}{r}0.210 \\
(0.214)\end{array}$ & $\begin{array}{r}0.083 \\
(0.231)\end{array}$ & $\begin{array}{r}0.167 \\
(0.226)\end{array}$ \\
\hline $\begin{array}{l}\text { Household monthly income, ref: less than } \\
\text { between } 5,000 \text { and } 10,000 \text { INR }\end{array}$ &, $000 \mathrm{INR}$ & $\begin{array}{r}-0.313 \\
(0.418)\end{array}$ & $\begin{array}{r}-0.259 \\
(0.413)\end{array}$ & $\begin{array}{r}-0.398 \\
(0.477)\end{array}$ & $\begin{array}{r}-0.345 \\
(0.448)\end{array}$ \\
\hline between 10,000 and 15,000 INR & & $\begin{array}{l}-0.843^{\star \star} \\
(0.381)\end{array}$ & $\begin{array}{l}-0.773^{\star \star} \\
(0.392)\end{array}$ & $\begin{array}{r}-0.571 \\
(0.463)\end{array}$ & $\begin{array}{r}-0.700 \\
(0.439)\end{array}$ \\
\hline between 15,000 and 20,000 INR & & $\begin{array}{r}-0.498 \\
(0.423)\end{array}$ & $\begin{array}{r}-0.449 \\
(0.427)\end{array}$ & $\begin{array}{r}-0.247 \\
(0.481)\end{array}$ & $\begin{array}{r}-0.357 \\
(0.460)\end{array}$ \\
\hline between 20,000 and 25,000 INR & & $\begin{array}{r}-0.615 \\
(0.414)\end{array}$ & $\begin{array}{l}-0.718^{\star} \\
(0.420)\end{array}$ & $\begin{array}{r}-0.445 \\
(0.464)\end{array}$ & $\begin{array}{r}-0.519 \\
(0.435)\end{array}$ \\
\hline above $25,000 \mathrm{INR}$ & & $\begin{array}{r}0.753 \\
(0.537)\end{array}$ & $\begin{array}{r}0.709 \\
(0.543)\end{array}$ & $\begin{array}{c}1.064^{\star} \\
(0.621)\end{array}$ & $\begin{array}{r}0.801 \\
(0.604)\end{array}$ \\
\hline Contribution to hh income (share) & & $\begin{array}{r}-0.047 \\
(0.095)\end{array}$ & $\begin{array}{r}-0.046 \\
(0.095)\end{array}$ & $\begin{array}{r}-0.021 \\
(0.107)\end{array}$ & $\begin{array}{r}-0.035 \\
(0.104)\end{array}$ \\
\hline \multicolumn{6}{|l|}{ Religion, ref: Hindu } \\
\hline Muslim & & & $\begin{array}{r}-0.325 \\
(0.292)\end{array}$ & $\begin{array}{r}-0.461 \\
(0.330)\end{array}$ & $\begin{array}{c}-0.508^{\star} \\
(0.308)\end{array}$ \\
\hline Sikh & & & $\begin{array}{r}-0.742 \\
(1.018)\end{array}$ & $\begin{array}{r}-1.055 \\
(1.056)\end{array}$ & $\begin{array}{r}-1.055 \\
(1.060)\end{array}$ \\
\hline Believes fate in god's hands $(=1)$ & & & $\begin{array}{r}0.156 \\
(0.317)\end{array}$ & $\begin{array}{r}0.068 \\
(0.364)\end{array}$ & $\begin{array}{r}0.312 \\
(0.334)\end{array}$ \\
\hline Caste $(=1)$ & & & $\begin{array}{r}-0.325 \\
(0.231)\end{array}$ & $\begin{array}{r}-0.117 \\
(0.247)\end{array}$ & $\begin{array}{r}-0.141 \\
(0.242)\end{array}$ \\
\hline \multicolumn{6}{|l|}{ Driving behaviors and safety perceptions } \\
\hline Uses motorbike to commute $(=1)$ & & & & $\begin{array}{r}0.061 \\
(0.328)\end{array}$ & \\
\hline Never uses ring roads $(=1)$ & & & & $\begin{array}{l}1.017^{\star \star} \\
(0.439)\end{array}$ & \\
\hline \# of persons on motorbike & & & & $\begin{array}{r}-0.304 \\
(0.194)\end{array}$ & \\
\hline Confident in own driving ability $(=1)$ & & & & $\begin{array}{r}-0.275 \\
(0.257)\end{array}$ & \\
\hline Took driving lessons $(=1)$ & & & & $\begin{array}{r}0.192 \\
(0.250)\end{array}$ & \\
\hline Experienced road traffic accident $(=1)$ & & & & $\begin{array}{r}-0.148 \\
(0.456)\end{array}$ & \\
\hline Underest. ann. road inj. $(=1)$ & & & & $\begin{array}{r}-0.258 \\
(0.261)\end{array}$ & \\
\hline Owns motorbike $(=1)$ & & & & $\begin{array}{r}-0.951 \\
(0.614)\end{array}$ & \\
\hline $\begin{array}{l}\text { Size of motorbike in cc, ref: } 100 \mathrm{cc} \text { or less } \\
\text { between } 100 \mathrm{cc} \text { and } 150 \mathrm{cc}\end{array}$ & & & & $\begin{array}{r}-0.177 \\
(0.297)\end{array}$ & \\
\hline above $150 \mathrm{cc}$ & & & & $\begin{array}{r}0.163 \\
(0.382)\end{array}$ & \\
\hline Has health insurance $(=1)$ & & & & $\begin{array}{l}0.039^{\star \star \star} \\
(0.013)\end{array}$ & \\
\hline Type of trips, ref: Short distance trip & & & & & \\
\hline Long distance trip & $\begin{array}{l}0.564^{\star \star \star} \\
(0.065)\end{array}$ & $\begin{array}{l}0.598^{\star \star \star} \\
(0.070)\end{array}$ & $\begin{array}{l}0.601^{\star \star \star} \\
(0.072)\end{array}$ & $\begin{array}{l}0.687^{\star \star \star} \\
(0.084)\end{array}$ & $\begin{array}{l}0.646^{\star \star \star} \\
(0.079)\end{array}$ \\
\hline Neighbourhood trip & $\begin{array}{l}-0.147^{\star \star} \\
(0.058)\end{array}$ & $\begin{array}{l}-0.163^{\star \star} \\
(0.063)\end{array}$ & $\begin{array}{l}-0.168^{\star \star \star} \\
(0.064)\end{array}$ & $\begin{array}{l}-0.200^{\star \star \star} \\
(0.075)\end{array}$ & $\begin{array}{l}-0.186^{\star \star \star} \\
(0.071)\end{array}$ \\
\hline Interviewer fixed effects & yes & yes & yes & yes & yes \\
\hline Pseudo $\mathrm{R}^{2}$ & 0.125 & 0.158 & 0.168 & 0.223 & 0.189 \\
\hline Observations & 1369 & 1324 & 1294 & 1178 & 1178 \\
\hline \# of respondents & 457 & 442 & 432 & 393 & 393 \\
\hline \# of observations per respondent (mean) & 2.99 & 2.99 & 2.99 & 2.99 & 2.99 \\
\hline
\end{tabular}


Table 6: Helmet use and speed level chosen by drivers, simultaneous equation system, coefficients

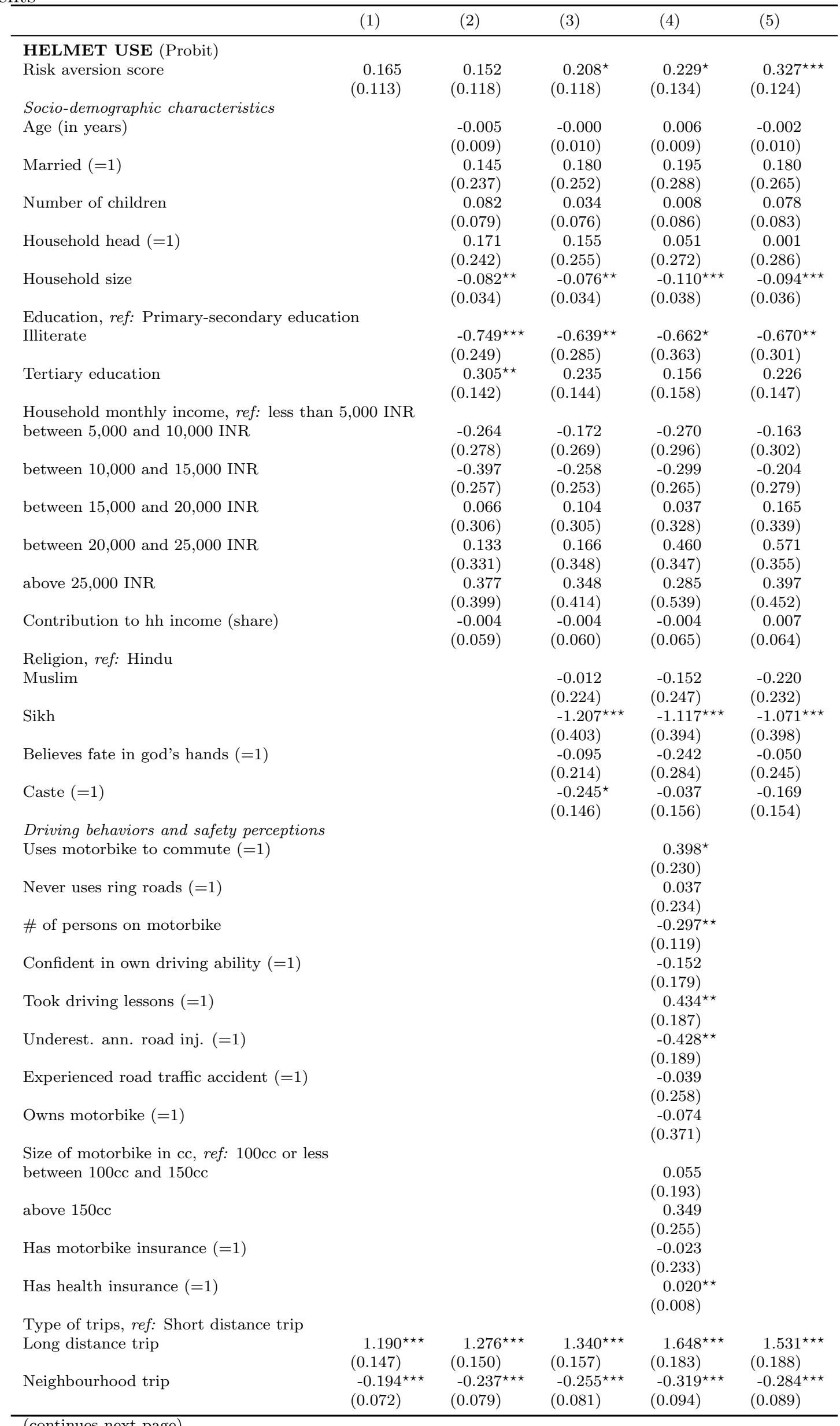

(continues next page) 
Table 6 (... continued $)$

\begin{tabular}{|c|c|c|c|c|c|}
\hline & (1) & $(2)$ & (3) & $(4)$ & $(5)$ \\
\hline \multicolumn{6}{|l|}{ SPEED (kph) (Linear model) } \\
\hline Risk aversion score & $\begin{array}{r}1.334 \\
(1.569)\end{array}$ & $\begin{array}{r}2.016 \\
(1.554)\end{array}$ & $\begin{array}{r}2.046 \\
(1.570)\end{array}$ & $\begin{array}{r}0.465 \\
(1.657)\end{array}$ & $\begin{array}{r}0.591 \\
(1.532)\end{array}$ \\
\hline \multicolumn{6}{|l|}{ Socio-demographic characteristics } \\
\hline Age (in years) & & $\begin{array}{r}-0.174 \\
(0.126)\end{array}$ & $\begin{array}{r}-0.112 \\
(0.125)\end{array}$ & $\begin{array}{r}-0.069 \\
(0.122)\end{array}$ & $\begin{array}{r}-0.087 \\
(0.121)\end{array}$ \\
\hline Married $(=1)$ & & $\begin{array}{c}7.296^{\star} \\
(3.733)\end{array}$ & $\begin{array}{c}6.919^{\star} \\
(3.692)\end{array}$ & $\begin{array}{r}5.013 \\
(3.620)\end{array}$ & $\begin{array}{r}5.426 \\
(3.788)\end{array}$ \\
\hline Number of children & & $\begin{array}{l}-2.675^{\star \star} \\
(1.285)\end{array}$ & $\begin{array}{l}-2.960^{\star \star} \\
(1.295)\end{array}$ & $\begin{array}{l}-3.446^{\star \star \star} \\
(1.165)\end{array}$ & $\begin{array}{l}-3.330^{\star \star \star} \\
(1.254)\end{array}$ \\
\hline Household head $(=1)$ & & $\begin{array}{r}3.167 \\
(2.961)\end{array}$ & $\begin{array}{r}3.229 \\
(2.833)\end{array}$ & $\begin{array}{r}3.506 \\
(2.737)\end{array}$ & $\begin{array}{r}3.412 \\
(2.854)\end{array}$ \\
\hline Household size & & $\begin{array}{r}-0.086 \\
(0.605)\end{array}$ & $\begin{array}{r}-0.102 \\
(0.588)\end{array}$ & $\begin{array}{r}0.247 \\
(0.547)\end{array}$ & $\begin{array}{r}0.164 \\
(0.533)\end{array}$ \\
\hline \multicolumn{6}{|l|}{ Education, ref: Primary-secondary education } \\
\hline Illiterate & & $\begin{array}{r}3.413 \\
(7.644)\end{array}$ & $\begin{array}{r}4.907 \\
(7.464)\end{array}$ & $\begin{array}{r}3.700 \\
(7.149)\end{array}$ & $\begin{array}{r}6.398 \\
(7.021)\end{array}$ \\
\hline Tertiary education & & $\begin{array}{r}-0.658 \\
(2.027)\end{array}$ & $\begin{array}{r}-0.299 \\
(2.013)\end{array}$ & $\begin{array}{r}1.384 \\
(2.101)\end{array}$ & $\begin{array}{r}0.791 \\
(2.074)\end{array}$ \\
\hline \multicolumn{6}{|c|}{ Household monthly income, ref: less than 5,000 INR } \\
\hline between 5,000 and 10,000 INR & & $\begin{array}{r}1.499 \\
(3.309)\end{array}$ & $\begin{array}{r}2.019 \\
(3.376)\end{array}$ & $\begin{array}{r}0.613 \\
(3.465)\end{array}$ & $\begin{array}{r}2.070 \\
(3.379)\end{array}$ \\
\hline between 10,000 and 15,000 INR & & $\begin{array}{l}7.445^{\star \star} \\
(3.559)\end{array}$ & $\begin{array}{l}8.184^{\star \star} \\
(3.689)\end{array}$ & $\begin{array}{r}3.978 \\
(3.727)\end{array}$ & $\begin{array}{c}6.167^{\star} \\
(3.665)\end{array}$ \\
\hline between 15,000 and 20,000 INR & & $\begin{array}{r}2.855 \\
(3.498)\end{array}$ & $\begin{array}{r}3.477 \\
(3.625)\end{array}$ & $\begin{array}{r}0.120 \\
(3.783)\end{array}$ & $\begin{array}{r}2.175 \\
(3.621)\end{array}$ \\
\hline between 20,000 and 25,000 INR & & $\begin{array}{r}5.344 \\
(3.702)\end{array}$ & $\begin{array}{c}6.875^{\star} \\
(3.740)\end{array}$ & $\begin{array}{r}3.143 \\
(3.931)\end{array}$ & $\begin{array}{r}5.426 \\
(3.825)\end{array}$ \\
\hline above $25,000 \mathrm{INR}$ & & $\begin{array}{c}-8.606^{\star} \\
(4.490)\end{array}$ & $\begin{array}{l}-8.424^{\star} \\
(4.609)\end{array}$ & $\begin{array}{l}-15.115^{\star \star \star} \\
(4.347)\end{array}$ & $\begin{array}{l}-10.970^{\star \star} \\
(4.607)\end{array}$ \\
\hline Contribution to hh income (share) & & $\begin{array}{r}0.604 \\
(0.705)\end{array}$ & $\begin{array}{r}0.628 \\
(0.691)\end{array}$ & $\begin{array}{r}0.603 \\
(0.643)\end{array}$ & $\begin{array}{r}0.695 \\
(0.652)\end{array}$ \\
\hline \multicolumn{6}{|l|}{ Religion, ref: Hindu } \\
\hline Muslim & & & $\begin{array}{r}0.069 \\
(2.457)\end{array}$ & $\begin{array}{r}0.170 \\
(2.529)\end{array}$ & $\begin{array}{r}-1.023 \\
(2.479)\end{array}$ \\
\hline Sikh & & & $\begin{array}{l}-11.714^{\star \star} \\
(4.749)\end{array}$ & $\begin{array}{l}-9.672^{\star \star} \\
(4.249)\end{array}$ & $\begin{array}{l}-8.353^{\star} \\
(4.275)\end{array}$ \\
\hline Believes fate in god's hands $(=1)$ & & & $\begin{array}{r}-5.891 \\
(3.805)\end{array}$ & $\begin{array}{r}0.071 \\
(3.474)\end{array}$ & $\begin{array}{r}-3.571 \\
(3.201)\end{array}$ \\
\hline Caste $(=1)$ & & & $\begin{array}{r}1.964 \\
(2.258)\end{array}$ & $\begin{array}{r}0.704 \\
(2.134)\end{array}$ & $\begin{array}{r}0.509 \\
(2.306)\end{array}$ \\
\hline \multicolumn{6}{|l|}{ Driving behaviors and safety perceptions } \\
\hline Uses motorbike to commute $(=1)$ & & & & $\begin{array}{r}0.902 \\
(2.603)\end{array}$ & \\
\hline Never uses ring roads $(=1)$ & & & & $\begin{array}{l}-6.882^{\star \star \star} \\
(2.442)\end{array}$ & \\
\hline \# of persons on motorbike & & & & $\begin{array}{r}1.982 \\
(2.221)\end{array}$ & \\
\hline Confident in own driving ability $(=1)$ & & & & $\begin{array}{r}-0.734 \\
(2.096)\end{array}$ & \\
\hline Took driving lessons $(=1)$ & & & & $\begin{array}{r}1.231 \\
(1.963)\end{array}$ & \\
\hline Underest. ann. road inj. $(=1)$ & & & & $\begin{array}{r}3.191 \\
(2.444)\end{array}$ & \\
\hline Experienced road traffic accident $(=1)$ & & & & $\begin{array}{r}-0.233 \\
(3.324)\end{array}$ & \\
\hline Owns motorbike $(=1)$ & & & & $\begin{array}{r}5.979 \\
(3.824)\end{array}$ & \\
\hline $\begin{array}{l}\text { Size of motorbike in cc, ref: } 100 \mathrm{cc} \text { or less } \\
\text { between } 100 \mathrm{cc} \text { and } 150 \mathrm{cc}\end{array}$ & & & & $\begin{array}{r}2.049 \\
(2.306)\end{array}$ & \\
\hline above $150 \mathrm{cc}$ & & & & $\begin{array}{r}3.462 \\
(3.268)\end{array}$ & \\
\hline Has motorbike insurance $(=1)$ & & & & $\begin{array}{r}0.954 \\
(2.381)\end{array}$ & \\
\hline Has health insurance $(=1)$ & & & & $\begin{array}{l}-0.139^{\star \star} \\
(0.061)\end{array}$ & \\
\hline Type of trips, ref: Short distance trip & & & & & \\
\hline Long distance trip & $\begin{array}{r}0.012 \\
(0.022)\end{array}$ & $\begin{array}{r}0.014 \\
(0.024)\end{array}$ & $\begin{array}{r}0.029 \\
(0.033)\end{array}$ & $\begin{array}{r}0.022 \\
(0.024)\end{array}$ & $\begin{array}{r}0.024 \\
(0.028)\end{array}$ \\
\hline Neighbourhood trip & $\begin{array}{r}0.003 \\
(0.022)\end{array}$ & $\begin{array}{r}0.011 \\
(0.025)\end{array}$ & $\begin{array}{r}0.006 \\
(0.032)\end{array}$ & $\begin{array}{r}-0.004 \\
(0.022)\end{array}$ & $\begin{array}{r}-0.002 \\
(0.025)\end{array}$ \\
\hline Interviewer fixed effects & yes & yes & yes & yes & yes \\
\hline Correlation residuals & $-0.096^{\star}$ & $-0.110^{\star}$ & $-0.155^{\star \star}$ & -0.120 & $-0.126^{\star}$ \\
\hline Observations & 1367 & 1328 & 1295 & 1160 & 1160 \\
\hline \# of respondents & 456 & 443 & 432 & 387 & 387 \\
\hline \# of observations per respondent (mean) & 3.00 & 3.00 & 3.00 & 3.00 & 3.00 \\
\hline
\end{tabular}


Table 7: Determinants of helmet use for passengers, probit specification, marginal effects

\begin{tabular}{|c|c|c|c|c|c|c|c|c|}
\hline & (1) & $(2)$ & $(3)$ & $(4)$ & (5) & $(6)$ & $(7)$ & $(8)$ \\
\hline Risk aversion score & $\begin{array}{r}-0.063 \\
(0.040)\end{array}$ & $\begin{array}{r}-0.056 \\
(0.044)\end{array}$ & $\begin{array}{r}-0.067 \\
(0.046)\end{array}$ & $\begin{array}{r}-0.019 \\
(0.034)\end{array}$ & $\begin{array}{r}-0.054 \\
(0.040)\end{array}$ & $\begin{array}{r}-0.014 \\
(0.033)\end{array}$ & $\begin{array}{r}-0.019 \\
(0.021)\end{array}$ & $\begin{array}{r}-0.057 \\
(0.049)\end{array}$ \\
\hline \multicolumn{9}{|l|}{$\begin{array}{l}\text { Speed, ref: between } 20 \text { and } 40 \mathrm{kph} \\
\text { below } 20 \mathrm{kph}\end{array}$} \\
\hline below $20 \mathrm{kph}$ & & & & & $\begin{array}{l}-0.114^{\star} \\
(0.064)\end{array}$ & $\begin{array}{l}-0.093^{\star} \\
(0.054)\end{array}$ & & \\
\hline above $40 \mathrm{kph}$ & & & & & $\begin{array}{l}-0.063 \\
(0.062)\end{array}$ & $\begin{array}{l}-0.042 \\
(0.050)\end{array}$ & & \\
\hline Owns a helmet $(=1)$ & & & & & & & $\begin{array}{l}0.314^{\star \star \star} \\
(0.120)\end{array}$ & \\
\hline \multicolumn{9}{|l|}{ Socio-demographic characteristics } \\
\hline Age (in years) & & $\begin{array}{r}-0.003 \\
(0.002)\end{array}$ & $\begin{array}{r}-0.003 \\
(0.002)\end{array}$ & $\begin{array}{l}-0.003^{\star} \\
(0.002)\end{array}$ & & $\begin{array}{l}-0.003^{\star} \\
(0.002)\end{array}$ & $\begin{array}{r}-0.002 \\
(0.001)\end{array}$ & $\begin{array}{l}-0.004^{\star} \\
(0.002)\end{array}$ \\
\hline Male $(=1)$ & & $\begin{array}{l}0.412^{\star \star \star} \\
(0.076)\end{array}$ & $\begin{array}{l}0.426^{\star \star \star} \\
(0.075)\end{array}$ & $\begin{array}{l}0.401^{\star \star \star} \\
(0.111)\end{array}$ & & $\begin{array}{l}0.405^{\star \star \star} \\
(0.110)\end{array}$ & $\begin{array}{l}0.242^{\star \star} \\
(0.108)\end{array}$ & $\begin{array}{l}0.429^{\star \star \star} \\
(0.082)\end{array}$ \\
\hline Married (=1) & & $\begin{array}{r}0.047 \\
(0.066)\end{array}$ & $\begin{array}{r}0.051 \\
(0.069)\end{array}$ & $\begin{array}{r}0.049 \\
(0.053)\end{array}$ & & $\begin{array}{r}0.045 \\
(0.052)\end{array}$ & $\begin{array}{r}0.023 \\
(0.033)\end{array}$ & $\begin{array}{r}0.071 \\
(0.080)\end{array}$ \\
\hline Number of children & & $\begin{array}{r}-0.009 \\
(0.024)\end{array}$ & $\begin{array}{r}0.003 \\
(0.025)\end{array}$ & $\begin{array}{r}0.008 \\
(0.018)\end{array}$ & & $\begin{array}{r}0.007 \\
(0.018)\end{array}$ & $\begin{array}{r}0.007 \\
(0.011)\end{array}$ & $\begin{array}{r}0.008 \\
(0.027)\end{array}$ \\
\hline Household head (=1) & & $\begin{array}{r}-0.088 \\
(0.085)\end{array}$ & $\begin{array}{r}-0.073 \\
(0.087)\end{array}$ & $\begin{array}{r}-0.034 \\
(0.069)\end{array}$ & & $\begin{array}{l}-0.051 \\
(0.065)\end{array}$ & $\begin{array}{r}-0.031 \\
(0.040)\end{array}$ & $\begin{array}{r}-0.082 \\
(0.092)\end{array}$ \\
\hline Household size & & $\begin{array}{r}0.013 \\
(0.011)\end{array}$ & $\begin{array}{r}0.009 \\
(0.011)\end{array}$ & $\begin{array}{r}0.003 \\
(0.009)\end{array}$ & & $\begin{array}{r}0.003 \\
(0.009)\end{array}$ & $\begin{array}{r}0.000 \\
(0.005)\end{array}$ & $\begin{array}{r}0.003 \\
(0.012)\end{array}$ \\
\hline \multicolumn{9}{|l|}{ Education, ref: Primary-secondary education } \\
\hline Illiterate & & $\begin{array}{r}-0.102 \\
(0.081)\end{array}$ & $\begin{array}{r}-0.082 \\
(0.084)\end{array}$ & $\begin{array}{r}-0.068 \\
(0.059)\end{array}$ & & $\begin{array}{r}-0.057 \\
(0.059)\end{array}$ & $\begin{array}{r}-0.021 \\
(0.036)\end{array}$ & $\begin{array}{r}-0.077 \\
(0.089)\end{array}$ \\
\hline Tertiary education & & $\begin{array}{r}-0.070 \\
(0.060)\end{array}$ & $\begin{array}{r}-0.093 \\
(0.062)\end{array}$ & $\begin{array}{r}-0.071 \\
(0.053)\end{array}$ & & $\begin{array}{r}-0.069 \\
(0.052)\end{array}$ & $\begin{array}{r}-0.020 \\
(0.029)\end{array}$ & $\begin{array}{r}-0.112 \\
(0.069)\end{array}$ \\
\hline \multicolumn{9}{|l|}{ Household monthly income, ref: less than 10,000 INR } \\
\hline between 10,000 and 20,000 INR & & $\begin{array}{r}-0.062 \\
(0.062)\end{array}$ & $\begin{array}{r}-0.057 \\
(0.063)\end{array}$ & $\begin{array}{r}-0.013 \\
(0.051)\end{array}$ & & $\begin{array}{r}-0.011 \\
(0.050)\end{array}$ & $\begin{array}{r}-0.021 \\
(0.029)\end{array}$ & $\begin{array}{r}-0.021 \\
(0.069)\end{array}$ \\
\hline above $20,000 \mathrm{INR}$ & & $\begin{array}{r}0.059 \\
(0.090)\end{array}$ & $\begin{array}{r}0.026 \\
(0.090)\end{array}$ & $\begin{array}{r}0.001 \\
(0.069)\end{array}$ & & $\begin{array}{r}0.018 \\
(0.071)\end{array}$ & $\begin{array}{r}-0.037 \\
(0.038)\end{array}$ & $\begin{array}{r}-0.007 \\
(0.102)\end{array}$ \\
\hline \multicolumn{9}{|l|}{ Religion, ref: Hindu } \\
\hline Muslim & & & $\begin{array}{r}0.033 \\
(0.094)\end{array}$ & $\begin{array}{r}0.035 \\
(0.077)\end{array}$ & & $\begin{array}{r}0.019 \\
(0.073)\end{array}$ & $\begin{array}{r}0.024 \\
(0.050)\end{array}$ & $\begin{array}{r}0.061 \\
(0.103)\end{array}$ \\
\hline Sikh & & & $\begin{array}{r}-0.025 \\
(0.128)\end{array}$ & $\begin{array}{r}-0.045 \\
(0.067)\end{array}$ & & $\begin{array}{r}-0.025 \\
(0.069)\end{array}$ & $\begin{array}{r}-0.056 \\
(0.037)\end{array}$ & $\begin{array}{r}-0.011 \\
(0.127)\end{array}$ \\
\hline Believes fate in god's hands $(=1)$ & & & $\begin{array}{r}-0.046 \\
(0.090)\end{array}$ & $\begin{array}{r}-0.039 \\
(0.084)\end{array}$ & & $\begin{array}{l}-0.017 \\
(0.076)\end{array}$ & $\begin{array}{r}-0.024 \\
(0.052)\end{array}$ & $\begin{array}{r}-0.058 \\
(0.106)\end{array}$ \\
\hline Caste $(=1)$ & & & $\begin{array}{l}-0.110^{\star \star} \\
(0.055)\end{array}$ & $\begin{array}{l}-0.090^{\star} \\
(0.048)\end{array}$ & & $\begin{array}{l}-0.087^{\star} \\
(0.047)\end{array}$ & $\begin{array}{r}-0.042 \\
(0.033)\end{array}$ & $\begin{array}{l}-0.145^{\star \star} \\
(0.060)\end{array}$ \\
\hline \multicolumn{9}{|l|}{ Driving behaviors and safety perceptions } \\
\hline Uses motorbike to commute $(=1)$ & & & & $\begin{array}{r}-0.010 \\
(0.050)\end{array}$ & & $\begin{array}{r}-0.010 \\
(0.048)\end{array}$ & $\begin{array}{r}-0.018 \\
(0.026)\end{array}$ & \\
\hline Never uses ring roads $(=1)$ & & & & $\begin{array}{r}0.035 \\
(0.067)\end{array}$ & & $\begin{array}{r}0.059 \\
(0.071)\end{array}$ & $\begin{array}{r}0.027 \\
(0.044)\end{array}$ & \\
\hline \multicolumn{9}{|l|}{ Size of motorbike in cc, ref: $100 \mathrm{cc}$ or less } \\
\hline between $100 \mathrm{cc}$ and $150 \mathrm{cc}$ & & & & $\begin{array}{r}0.077 \\
(0.053)\end{array}$ & & $\begin{array}{r}0.077 \\
(0.053)\end{array}$ & $\begin{array}{r}0.024 \\
(0.035)\end{array}$ & \\
\hline above $150 \mathrm{cc}$ & & & & $\begin{array}{r}0.222 \\
(0.137)\end{array}$ & & $\begin{array}{r}0.195 \\
(0.133)\end{array}$ & $\begin{array}{r}0.060 \\
(0.081)\end{array}$ & \\
\hline Experienced road traffic accident $(=1)$ & & & & $\begin{array}{r}-0.081 \\
(0.056)\end{array}$ & & $\begin{array}{r}-0.079 \\
(0.056)\end{array}$ & $\begin{array}{r}-0.032 \\
(0.031)\end{array}$ & \\
\hline Underest. ann. road inj. $(=1)$ & & & & $\begin{array}{l}-0.142^{\star \star} \\
(0.065)\end{array}$ & & $\begin{array}{l}-0.136^{\star \star} \\
(0.063)\end{array}$ & $\begin{array}{l}-0.091^{\star} \\
(0.053)\end{array}$ & \\
\hline Has health insurance $(=1)$ & & & & $\begin{array}{l}-0.122^{\star \star \star} \\
(0.035)\end{array}$ & & $\begin{array}{l}-0.125^{\star \star \star} \\
(0.031)\end{array}$ & $\begin{array}{l}-0.116^{\star \star \star} \\
(0.020)\end{array}$ & \\
\hline Says own driver should pay more attention $(=1)$ & & & & $\begin{array}{l}-0.123^{\star} \\
(0.066)\end{array}$ & & $\begin{array}{l}-0.120^{\star} \\
(0.068)\end{array}$ & $\begin{array}{l}-0.090^{\star} \\
(0.051)\end{array}$ & \\
\hline Type of trips, ref: Short distance trip & & & & & & & & \\
\hline Long distance trip & $\begin{array}{l}0.262^{\star \star \star} \\
(0.026)\end{array}$ & $\begin{array}{l}0.298^{\star \star \star} \\
(0.029)\end{array}$ & $\begin{array}{l}0.296^{\star \star \star} \\
(0.029)\end{array}$ & $\begin{array}{l}0.275^{\star \star \star} \\
(0.066)\end{array}$ & $\begin{array}{l}0.264^{\star \star \star} \\
(0.026)\end{array}$ & $\begin{array}{l}0.273^{\star \star \star} \\
(0.065)\end{array}$ & $\begin{array}{l}0.230^{\star \star \star} \\
(0.089)\end{array}$ & $\begin{array}{l}0.336^{\star \star \star} \\
(0.034)\end{array}$ \\
\hline Neighbourhood trip & $\begin{array}{l}-0.063^{\star \star} \\
(0.028)\end{array}$ & $\begin{array}{l}-0.078^{\star \star} \\
(0.031)\end{array}$ & $\begin{array}{l}-0.078^{\star \star} \\
(0.031)\end{array}$ & $\begin{array}{l}-0.056^{\star} \\
(0.030)\end{array}$ & $\begin{array}{l}-0.065^{\star \star} \\
(0.028)\end{array}$ & $\begin{array}{l}-0.055^{\star} \\
(0.030)\end{array}$ & $\begin{array}{l}-0.038 \\
(0.025)\end{array}$ & $\begin{array}{l}-0.081^{\star \star} \\
(0.036)\end{array}$ \\
\hline Interviewer fixed effects & yes & yes & yes & yes & yes & yes & yes & yes \\
\hline Pseudo $\mathrm{R}^{2}$ & 0.151 & 0.247 & 0.255 & 0.309 & 0.159 & 0.315 & 0.440 & 0.267 \\
\hline Observations & 963 & 954 & 936 & 759 & 963 & 759 & 756 & 756 \\
\hline \# of respondents & 322 & 319 & 313 & 254 & 322 & 254 & 253 & 253 \\
\hline \# of observations per respondent (mean) & 2.99 & 2.99 & 2.99 & 2.99 & 2.99 & 2.99 & 2.99 & 2.99 \\
\hline
\end{tabular}


Table A1: Socio-demographic and economic correlates of missing information, probit specifications, coefficients

\begin{tabular}{|c|c|c|c|c|}
\hline & \multicolumn{2}{|c|}{ Male drivers } & \multicolumn{2}{|c|}{ All passengers } \\
\hline Male $(=1)$ & & & $\begin{array}{c}-0.753^{\star \star \star} \\
(0.194)\end{array}$ & $\begin{array}{c}-0.649^{\star \star} \\
(0.282)\end{array}$ \\
\hline Age (in years) & $\begin{array}{l}-0.005 \\
(0.005)\end{array}$ & $\begin{array}{l}-0.006 \\
(0.009)\end{array}$ & $\begin{array}{l}0.010^{\star} \\
(0.006)\end{array}$ & $\begin{array}{c}0.010 \\
(0.007)\end{array}$ \\
\hline Education level (3 categories) & $\begin{array}{c}0.006 \\
(0.117)\end{array}$ & $\begin{array}{c}0.054 \\
(0.130)\end{array}$ & $\begin{array}{c}0.012 \\
(0.109)\end{array}$ & $\begin{array}{l}-0.060 \\
(0.133)\end{array}$ \\
\hline HH monthly income, ref: Less than & $0,000 \mathrm{INR}$ & & & \\
\hline Between 10,000 and 20,000 INR & $\begin{array}{c}0.079 \\
(0.186)\end{array}$ & $\begin{array}{l}-0.009 \\
(0.204)\end{array}$ & $\begin{array}{c}0.044 \\
(0.177)\end{array}$ & $\begin{array}{c}-0.017 \\
(0.191)\end{array}$ \\
\hline More than 20,000 INR & $\begin{array}{c}0.012 \\
(0.220)\end{array}$ & $\begin{array}{l}-0.174 \\
(0.255)\end{array}$ & $\begin{array}{c}-0.268 \\
(0.240)\end{array}$ & $\begin{array}{c}-0.529^{\star \star} \\
(0.262)\end{array}$ \\
\hline Married (=1) & & $\begin{array}{c}0.131 \\
(0.282)\end{array}$ & & $\begin{array}{l}-0.214 \\
(0.254)\end{array}$ \\
\hline Number of children & & $\begin{array}{l}-0.044 \\
(0.089)\end{array}$ & & $\begin{array}{l}-0.051 \\
(0.083)\end{array}$ \\
\hline Head of household $(=1)$ & & $\begin{array}{l}-0.122 \\
(0.243)\end{array}$ & & $\begin{array}{c}0.264 \\
(0.364)\end{array}$ \\
\hline Household size & & $\begin{array}{c}0.025 \\
(0.042)\end{array}$ & & $\begin{array}{c}0.039 \\
(0.031)\end{array}$ \\
\hline Contributes to $\mathrm{HH}$ income (share) & & $\begin{array}{c}0.057 \\
(0.067)\end{array}$ & & $\begin{array}{c}-0.220^{\star \star} \\
(0.111)\end{array}$ \\
\hline Religion, ref: Hindu & & & & \\
\hline Muslim & & $\begin{array}{l}-0.235 \\
(0.253)\end{array}$ & & $\begin{array}{l}-0.309 \\
(0.300)\end{array}$ \\
\hline Sikh & & $\begin{array}{l}-0.395 \\
(0.455)\end{array}$ & & $\begin{array}{l}-1.013^{\star} \\
(0.569)\end{array}$ \\
\hline Believes fate is in god's hands & & $\begin{array}{l}-0.344 \\
(0.221)\end{array}$ & & $\begin{array}{l}-0.250 \\
(0.235)\end{array}$ \\
\hline Belongs to low caste $(=1)$ & & $\begin{array}{l}-0.189 \\
(0.172)\end{array}$ & & $\begin{array}{c}-0.563^{\star \star \star} \\
(0.182)\end{array}$ \\
\hline Constant & $\begin{array}{c}-0.936^{\star \star \star} \\
(0.345)\end{array}$ & $\begin{array}{c}-0.967^{\star} \\
(0.510)\end{array}$ & $\begin{array}{c}-0.853^{\star \star} \\
(0.343)\end{array}$ & $\begin{array}{l}-0.174 \\
(0.484)\end{array}$ \\
\hline Pseudo $\mathrm{R}^{2}$ & 0.006 & 0.023 & 0.052 & 0.122 \\
\hline Observations & 482 & 456 & 368 & 354 \\
\hline Total observations in survey & 489 & 489 & 371 & 371 \\
\hline Share of observations in sample (\%) & 98.50 & 93.25 & 99.00 & 95.40 \\
\hline
\end{tabular}

Notes: ${ }^{\star \star \star},{ }^{\star \star}$ and ${ }^{\star}$ stands for $1 \%, 5 \%$ and $10 \%$ significance respectively. Robust standard errors reported in parentheses. 
Table A2a: Level of protection chosen by drivers, ordered logit specification, marginal effects

\begin{tabular}{|c|c|c|c|c|c|}
\hline $\operatorname{Pr}($ no protection $)$ & $(1)$ & $(2)$ & $(3)$ & $(4)$ & $(5)$ \\
\hline Risk aversion score & $\begin{array}{r}-0.017 \\
(0.012)\end{array}$ & $\begin{array}{c}-0.014 \\
(0.011)\end{array}$ & $\begin{array}{r}-0.017 \\
(0.011)\end{array}$ & $\begin{array}{l}-0.019^{\star \star} \\
(0.010)\end{array}$ & $\begin{array}{l}-0.023^{\star \star} \\
(0.011)\end{array}$ \\
\hline \multicolumn{6}{|l|}{ Socio-demographic characteristics } \\
\hline Age (in years) & & $\begin{array}{r}-0.001 \\
(0.001)\end{array}$ & $\begin{array}{r}-0.000 \\
(0.001)\end{array}$ & $\begin{array}{c}-0.000 \\
(0.001)\end{array}$ & $\begin{array}{r}-0.000 \\
(0.001)\end{array}$ \\
\hline Married (=1) & & $\begin{array}{r}0.027 \\
(0.021)\end{array}$ & $\begin{array}{r}0.028 \\
(0.021)\end{array}$ & $\begin{array}{r}0.013 \\
(0.018)\end{array}$ & $\begin{array}{r}0.018 \\
(0.021)\end{array}$ \\
\hline Number of children & & $\begin{array}{l}-0.018^{\star \star} \\
(0.008)\end{array}$ & $\begin{array}{l}-0.018^{\star \star} \\
(0.007)\end{array}$ & $\begin{array}{l}-0.016^{\star \star} \\
(0.006)\end{array}$ & $\begin{array}{l}-0.020^{\star \star \star} \\
(0.007)\end{array}$ \\
\hline Household head $(=1)$ & & $\begin{array}{r}0.022 \\
(0.021)\end{array}$ & $\begin{array}{r}0.022 \\
(0.020)\end{array}$ & $\begin{array}{r}0.029 \\
(0.018)\end{array}$ & $\begin{array}{r}0.034 \\
(0.021)\end{array}$ \\
\hline Household size & & $\begin{array}{c}0.006^{\star} \\
(0.004)\end{array}$ & $\begin{array}{r}0.005 \\
(0.003)\end{array}$ & $\begin{array}{c}0.005^{\star} \\
(0.003)\end{array}$ & $\begin{array}{l}0.007^{\star \star} \\
(0.003)\end{array}$ \\
\hline \multicolumn{6}{|c|}{ Education, ref: Primary-secondary education } \\
\hline Illiterate & & $\begin{array}{c}0.076^{\star} \\
(0.039)\end{array}$ & $\begin{array}{c}0.065^{\star} \\
(0.039)\end{array}$ & $\begin{array}{r}0.047 \\
(0.033)\end{array}$ & $\begin{array}{c}0.064^{\star} \\
(0.035)\end{array}$ \\
\hline Tertiary education & & $\begin{array}{r}-0.016 \\
(0.013)\end{array}$ & $\begin{array}{r}-0.013 \\
(0.013)\end{array}$ & $\begin{array}{c}-0.004 \\
(0.011)\end{array}$ & $\begin{array}{r}-0.009 \\
(0.013)\end{array}$ \\
\hline \multicolumn{6}{|c|}{ Household monthly income, ref: less than 5,000 INR } \\
\hline between 5,000 and 10,000 INR & & $(0.026)$ & $(0.025)$ & $(0.023)$ & $(0.025)$ \\
\hline between 10,000 and 15,000 INR & & $\begin{array}{c}0.053^{\star \star} \\
(0.024)\end{array}$ & $\begin{array}{l}0.047^{\star \star} \\
(0.023)\end{array}$ & $\begin{array}{r}0.028 \\
(0.022)\end{array}$ & $\begin{array}{r}0.039 \\
(0.024)\end{array}$ \\
\hline between 15,000 and 20,000 INR & & $\begin{array}{r}0.032 \\
(0.027)\end{array}$ & $\begin{array}{r}0.027 \\
(0.026)\end{array}$ & $\begin{array}{r}0.012 \\
(0.023)\end{array}$ & $\begin{array}{r}0.020 \\
(0.025)\end{array}$ \\
\hline between 20,000 and 25,000 INR & & $\begin{array}{r}0.039 \\
(0.026)\end{array}$ & $\begin{array}{c}0.043^{\star} \\
(0.025)\end{array}$ & $\begin{array}{r}0.022 \\
(0.022)\end{array}$ & $\begin{array}{r}0.029 \\
(0.024)\end{array}$ \\
\hline above $25,000 \mathrm{INR}$ & & $\begin{array}{r}-0.048 \\
(0.034)\end{array}$ & $\begin{array}{r}-0.043 \\
(0.033)\end{array}$ & $\begin{array}{c}-0.052^{\star} \\
(0.031)\end{array}$ & $\begin{array}{r}-0.045 \\
(0.034)\end{array}$ \\
\hline Contribution to hh income (share) & & $\begin{array}{r}0.003 \\
(0.006)\end{array}$ & $\begin{array}{r}0.003 \\
(0.006)\end{array}$ & $\begin{array}{r}0.001 \\
(0.005)\end{array}$ & $\begin{array}{r}0.002 \\
(0.006)\end{array}$ \\
\hline \multicolumn{6}{|l|}{ Religion, ref: Hindu } \\
\hline Muslim & & & $\begin{array}{r}0.020 \\
(0.018)\end{array}$ & $\begin{array}{r}0.023 \\
(0.016)\end{array}$ & $\begin{array}{c}0.029^{\star} \\
(0.017)\end{array}$ \\
\hline Sikh & & & $\begin{array}{r}0.045 \\
(0.062)\end{array}$ & $\begin{array}{r}0.052 \\
(0.052)\end{array}$ & $\begin{array}{r}0.059 \\
(0.060)\end{array}$ \\
\hline Believes fate in god's hands $(=1)$ & & & $\begin{array}{r}-0.009 \\
(0.019)\end{array}$ & $\begin{array}{c}-0.003 \\
(0.018)\end{array}$ & $\begin{array}{r}-0.018 \\
(0.019)\end{array}$ \\
\hline Caste $(=1)$ & & & $\begin{array}{r}0.020 \\
(0.014)\end{array}$ & $\begin{array}{r}0.006 \\
(0.012)\end{array}$ & $\begin{array}{r}0.008 \\
(0.014)\end{array}$ \\
\hline \multicolumn{6}{|l|}{ Driving behaviors and safety perceptions } \\
\hline Uses motorbike to commute $(=1)$ & & & & $\begin{array}{r}-0.003 \\
(0.016)\end{array}$ & \\
\hline Never uses ring roads $(=1)$ & & & & $\begin{array}{l}-0.050^{\star \star} \\
(0.021)\end{array}$ & \\
\hline \# of persons on motorbike & & & & $\begin{array}{r}0.015 \\
(0.010)\end{array}$ & \\
\hline Confident in own driving ability $(=1)$ & & & & $\begin{array}{r}0.014 \\
(0.013)\end{array}$ & \\
\hline Took driving lessons $(=1)$ & & & & $\begin{array}{r}-0.009 \\
(0.012)\end{array}$ & \\
\hline Underest. ann. road inj. $(=1)$ & & & & $\begin{array}{r}0.013 \\
(0.013)\end{array}$ & \\
\hline Experienced road traffic accident $(=1)$ & & & & $\begin{array}{r}0.007 \\
(0.022)\end{array}$ & \\
\hline Owns motorbike $(=1)$ & & & & $\begin{array}{r}0.047 \\
(0.029)\end{array}$ & \\
\hline $\begin{array}{l}\text { Size of motorbike in cc, ref: } 100 \mathrm{cc} \text { or } 1 \\
\text { between } 100 \mathrm{cc} \text { and } 150 \mathrm{cc}\end{array}$ & & & & $\begin{array}{r}0.009 \\
(0.015)\end{array}$ & \\
\hline above $150 \mathrm{cc}$ & & & & $\begin{array}{r}-0.008 \\
(0.019)\end{array}$ & \\
\hline Has health insurance $(=1)$ & & & & $\begin{array}{l}-0.002^{\star \star \star} \\
(0.001)\end{array}$ & \\
\hline Type of trips, ref: Short distance trip & & & & & \\
\hline Long distance trip & $\begin{array}{l}-0.040^{\star \star \star} \\
(0.007)\end{array}$ & $\begin{array}{l}-0.038^{\star \star \star} \\
(0.007)\end{array}$ & $\begin{array}{l}-0.036^{\star \star \star} \\
(0.006)\end{array}$ & $\begin{array}{l}-0.034^{\star \star \star} \\
(0.006)\end{array}$ & $\begin{array}{l}-0.036^{\star \star \star} \\
(0.007)\end{array}$ \\
\hline Neighbourhood trip & $\begin{array}{c}0.010^{\star \star} \\
(0.004)\end{array}$ & $\begin{array}{c}0.010^{\star \star} \\
(0.004)\end{array}$ & $\begin{array}{c}0.010^{\star \star \star} \\
(0.004)\end{array}$ & $\begin{array}{l}0.010^{\star \star \star} \\
(0.004)\end{array}$ & $\begin{array}{c}0.010^{\star \star \star} \\
(0.004)\end{array}$ \\
\hline Interviewer fixed effects & yes & yes & yes & yes & yes \\
\hline Pseudo $\mathrm{R}^{2}$ & 0.125 & 0.158 & 0.168 & 0.223 & 0.189 \\
\hline Observations & 1369 & 1324 & 1294 & 1178 & 1178 \\
\hline
\end{tabular}


Table A2b: Level of protection chosen by drivers, ordered logit specification, marginal effects

\begin{tabular}{|c|c|c|c|c|c|}
\hline $\operatorname{Pr}($ partial protection) & $(1)$ & $(2)$ & $(3)$ & $(4)$ & $(5)$ \\
\hline Risk aversion score & $\begin{array}{r}-0.041 \\
(0.027)\end{array}$ & $\begin{array}{r}-0.039 \\
(0.030)\end{array}$ & $\begin{array}{r}-0.048 \\
(0.031)\end{array}$ & $\begin{array}{l}-0.074^{\star \star} \\
(0.038)\end{array}$ & $\begin{array}{l}-0.076^{\star \star} \\
(0.035)\end{array}$ \\
\hline \multicolumn{6}{|l|}{ Socio-demographic characteristics } \\
\hline Age (in years) & & $\begin{array}{r}-0.001 \\
(0.002)\end{array}$ & $\begin{array}{r}-0.001 \\
(0.002)\end{array}$ & $\begin{array}{r}-0.001 \\
(0.003)\end{array}$ & $\begin{array}{r}-0.000 \\
(0.002)\end{array}$ \\
\hline Married (=1) & & $\begin{array}{r}0.073 \\
(0.058)\end{array}$ & $\begin{array}{r}0.082 \\
(0.061)\end{array}$ & $\begin{array}{r}0.050 \\
(0.072)\end{array}$ & $\begin{array}{r}0.058 \\
(0.068)\end{array}$ \\
\hline Number of children & & $\begin{array}{l}-0.047^{\star \star} \\
(0.021)\end{array}$ & $\begin{array}{l}-0.051^{\star \star} \\
(0.022)\end{array}$ & $\begin{array}{l}-0.061^{\star \star} \\
(0.025)\end{array}$ & $\begin{array}{l}-0.065^{\star \star \star} \\
(0.025)\end{array}$ \\
\hline Household head $(=1)$ & & $\begin{array}{r}0.061 \\
(0.056)\end{array}$ & $\begin{array}{r}0.063 \\
(0.058)\end{array}$ & $\begin{array}{r}0.112 \\
(0.073)\end{array}$ & $\begin{array}{r}0.113 \\
(0.070)\end{array}$ \\
\hline Household size & & $\begin{array}{c}0.018^{\star} \\
(0.009)\end{array}$ & $\begin{array}{r}0.016 \\
(0.010)\end{array}$ & $\begin{array}{c}0.021^{\star} \\
(0.011)\end{array}$ & $\begin{array}{l}0.021^{\star \star} \\
(0.010)\end{array}$ \\
\hline \multicolumn{6}{|c|}{ Education, ref: Primary-secondary education } \\
\hline Illiterate & & $\begin{array}{c}0.206^{\star} \\
(0.107)\end{array}$ & $\begin{array}{c}0.189^{\star} \\
(0.115)\end{array}$ & $\begin{array}{r}0.183 \\
(0.130)\end{array}$ & $\begin{array}{c}0.210^{\star} \\
(0.116)\end{array}$ \\
\hline Tertiary education & & $\begin{array}{r}-0.043 \\
(0.036)\end{array}$ & $\begin{array}{r}-0.037 \\
(0.038)\end{array}$ & $\begin{array}{r}-0.016 \\
(0.044)\end{array}$ & $\begin{array}{r}-0.031 \\
(0.042)\end{array}$ \\
\hline \multicolumn{6}{|c|}{ Household monthly income, ref: less than 5,000 INR } \\
\hline between 5,000 and 10,000 INR & & $(0.072)$ & $(0.073)$ & $(0.092)$ & $(0.083)$ \\
\hline between 10,000 and 15,000 INR & & $\begin{array}{c}0.145^{\star \star} \\
(0.068)\end{array}$ & $\begin{array}{l}0.136^{\star \star} \\
(0.071)\end{array}$ & $\begin{array}{r}0.109 \\
(0.090)\end{array}$ & $\begin{array}{r}0.129 \\
(0.083)\end{array}$ \\
\hline between 15,000 and 20,000 INR & & $\begin{array}{r}0.086 \\
(0.074)\end{array}$ & $\begin{array}{r}0.079 \\
(0.076)\end{array}$ & $\begin{array}{r}0.047 \\
(0.092)\end{array}$ & $\begin{array}{r}0.066 \\
(0.085)\end{array}$ \\
\hline between 20,000 and 25,000 INR & & $\begin{array}{r}0.106 \\
(0.072)\end{array}$ & $\begin{array}{c}0.126^{\star} \\
(0.075)\end{array}$ & $\begin{array}{r}0.085 \\
(0.089)\end{array}$ & $\begin{array}{r}0.096 \\
(0.081)\end{array}$ \\
\hline above 25,000 INR & & $\begin{array}{r}-0.130 \\
(0.093)\end{array}$ & $\begin{array}{r}-0.125 \\
(0.096)\end{array}$ & $\begin{array}{c}-0.203^{\star} \\
(0.119)\end{array}$ & $\begin{array}{r}-0.147 \\
(0.111)\end{array}$ \\
\hline Contribution to hh income (share) & & $\begin{array}{r}0.008 \\
(0.016)\end{array}$ & $\begin{array}{r}0.008 \\
(0.017)\end{array}$ & $\begin{array}{r}0.004 \\
(0.020)\end{array}$ & $\begin{array}{r}0.006 \\
(0.019)\end{array}$ \\
\hline \multicolumn{6}{|l|}{ Religion, ref: Hindu } \\
\hline Muslim & & & $\begin{array}{r}0.057 \\
(0.052)\end{array}$ & $\begin{array}{r}0.088 \\
(0.064)\end{array}$ & $\begin{array}{c}0.094^{\star} \\
(0.058)\end{array}$ \\
\hline Sikh & & & $\begin{array}{r}0.131 \\
(0.178)\end{array}$ & $\begin{array}{r}0.202 \\
(0.201)\end{array}$ & $\begin{array}{r}0.194 \\
(0.194)\end{array}$ \\
\hline Believes fate in god's hands $(=1)$ & & & $\begin{array}{r}-0.027 \\
(0.056)\end{array}$ & $\begin{array}{c}-0.013 \\
(0.070)\end{array}$ & $\begin{array}{r}-0.057 \\
(0.062)\end{array}$ \\
\hline Caste $(=1)$ & & & $\begin{array}{r}0.057 \\
(0.041)\end{array}$ & $\begin{array}{r}0.022 \\
(0.047)\end{array}$ & $\begin{array}{r}0.026 \\
(0.045)\end{array}$ \\
\hline \multicolumn{6}{|l|}{ Driving behaviors and safety perceptions } \\
\hline Uses motorbike to commute $(=1)$ & & & & $\begin{array}{r}-0.012 \\
(0.063)\end{array}$ & \\
\hline Never uses ring roads $(=1)$ & & & & $\begin{array}{l}-0.194^{\star \star} \\
(0.087)\end{array}$ & \\
\hline \# of persons on motorbike & & & & $\begin{array}{r}0.058 \\
(0.037)\end{array}$ & \\
\hline Confident in own driving ability $(=1)$ & & & & $\begin{array}{r}0.053 \\
(0.049)\end{array}$ & \\
\hline Took driving lessons $(=1)$ & & & & $\begin{array}{r}-0.037 \\
(0.048)\end{array}$ & \\
\hline Underest. ann. road inj. $(=1)$ & & & & $\begin{array}{r}0.049 \\
(0.050)\end{array}$ & \\
\hline Experienced road traffic accident $(=1)$ & & & & $\begin{array}{r}0.028 \\
(0.087)\end{array}$ & \\
\hline Owns motorbike $(=1)$ & & & & $\begin{array}{r}0.182 \\
(0.119)\end{array}$ & \\
\hline $\begin{array}{l}\text { Size of motorbike in cc, ref: } 100 \mathrm{cc} \text { or } 1 \\
\text { between } 100 \text { and } 150 \mathrm{cc}\end{array}$ & & & & $\begin{array}{r}0.034 \\
(0.057)\end{array}$ & \\
\hline above $150 \mathrm{cc}$ & & & & $\begin{array}{r}-0.031 \\
(0.073)\end{array}$ & \\
\hline Has health insurance $(=1)$ & & & & $\begin{array}{l}-0.007^{\star \star \star} \\
(0.003)\end{array}$ & \\
\hline Type of trips, ref: Short distance trip & & & & & \\
\hline Long distance trip & $\begin{array}{l}-0.095^{\star \star \star} \\
(0.011)\end{array}$ & $\begin{array}{l}-0.103^{\star \star \star} \\
(0.012)\end{array}$ & $\begin{array}{l}-0.106^{\star \star \star} \\
(0.013)\end{array}$ & $\begin{array}{l}-0.131^{\star \star \star} \\
(0.017)\end{array}$ & $\begin{array}{l}-0.119^{\star \star \star} \\
(0.015)\end{array}$ \\
\hline Neighbourhood trip & $\begin{array}{c}0.025^{\star \star} \\
(0.010)\end{array}$ & $\begin{array}{c}0.028^{\star \star} \\
(0.011)\end{array}$ & $\begin{array}{c}0.029^{\star \star \star} \\
(0.011)\end{array}$ & $\begin{array}{l}0.038^{\star \star \star} \\
(0.014)\end{array}$ & $\begin{array}{l}0.034^{\star \star \star} \\
(0.013)\end{array}$ \\
\hline Interviewer fixed effects & yes & yes & yes & yes & yes \\
\hline Pseudo $\mathrm{R}^{2}$ & 0.125 & 0.158 & 0.168 & 0.223 & 0.189 \\
\hline Observations & 1369 & 1324 & 1294 & 1178 & 1178 \\
\hline
\end{tabular}


Table A2c: Level of protection chosen by drivers, ordered logit specification, marginal effects

\begin{tabular}{|c|c|c|c|c|c|}
\hline $\operatorname{Pr}($ full protection) & $(1)$ & $(2)$ & $(3)$ & $(4)$ & $(5)$ \\
\hline Risk aversion score & $\begin{array}{r}0.058 \\
(0.039)\end{array}$ & $\begin{array}{r}0.054 \\
(0.041)\end{array}$ & $\begin{array}{r}0.065 \\
(0.041)\end{array}$ & $\begin{array}{l}0.093^{\star \star} \\
(0.047)\end{array}$ & $\begin{array}{l}0.099^{\star \star} \\
(0.045)\end{array}$ \\
\hline \multicolumn{6}{|l|}{ Socio-demographic characteristics } \\
\hline Age (in years) & & $\begin{array}{r}0.002 \\
(0.003)\end{array}$ & $\begin{array}{r}0.001 \\
(0.003)\end{array}$ & $\begin{array}{r}0.001 \\
(0.003)\end{array}$ & $\begin{array}{r}0.001 \\
(0.003)\end{array}$ \\
\hline Married (=1) & & $\begin{array}{r}-0.099 \\
(0.078)\end{array}$ & $\begin{array}{r}-0.110 \\
(0.081)\end{array}$ & $\begin{array}{r}-0.063 \\
(0.090)\end{array}$ & $\begin{array}{r}-0.075 \\
(0.089)\end{array}$ \\
\hline Number of children & & $\begin{array}{l}0.065^{\star \star} \\
(0.028)\end{array}$ & $\begin{array}{l}0.069^{\star \star} \\
(0.029)\end{array}$ & $\begin{array}{l}0.077^{\star \star} \\
(0.031)\end{array}$ & $\begin{array}{c}0.085^{\star \star \star} \\
(0.032)\end{array}$ \\
\hline Household head $(=1)$ & & $\begin{array}{c}-0.083 \\
(0.077)\end{array}$ & $\begin{array}{c}-0.084 \\
(0.078)\end{array}$ & $\begin{array}{l}-0.140 \\
(0.091)\end{array}$ & $\begin{array}{r}-0.147 \\
(0.090)\end{array}$ \\
\hline Household size & & $\begin{array}{c}-0.024^{\star} \\
(0.013)\end{array}$ & $\begin{array}{r}-0.021 \\
(0.013)\end{array}$ & $\begin{array}{c}-0.027^{\star} \\
(0.014)\end{array}$ & $\begin{array}{l}-0.028^{\star \star} \\
(0.014)\end{array}$ \\
\hline \multicolumn{6}{|c|}{ Education, ref: Primary-secondary education } \\
\hline Illiterate & & $\begin{array}{l}-0.281^{\star} \\
(0.144)\end{array}$ & $\begin{array}{c}-0.254^{\star} \\
(0.153)\end{array}$ & $\begin{array}{r}-0.230 \\
(0.162)\end{array}$ & $\begin{array}{c}-0.274^{\star} \\
(0.150)\end{array}$ \\
\hline Tertiary education & & $\begin{array}{r}0.059 \\
(0.049)\end{array}$ & $\begin{array}{r}0.050 \\
(0.051)\end{array}$ & $\begin{array}{r}0.020 \\
(0.056)\end{array}$ & $\begin{array}{r}0.040 \\
(0.054)\end{array}$ \\
\hline between 5,000 and 10,000 INR & $5,000 \mathrm{INR}$ & $\begin{array}{r}-0.074 \\
(0.098)\end{array}$ & $\begin{array}{r}-0.061 \\
(0.098)\end{array}$ & $\begin{array}{r}-0.096 \\
(0.115)\end{array}$ & $\begin{array}{r}-0.083 \\
(0.108)\end{array}$ \\
\hline between 10,000 and 15,000 INR & & $\begin{array}{l}-0.199^{\star \star} \\
(0.090)\end{array}$ & $\begin{array}{l}-0.183^{\star \star} \\
(0.093)\end{array}$ & $\begin{array}{r}-0.137 \\
(0.112)\end{array}$ & $\begin{array}{c}-0.168 \\
(0.106)\end{array}$ \\
\hline between 15,000 and 20,000 INR & & $\begin{array}{l}-0.117 \\
(0.100)\end{array}$ & $\begin{array}{r}-0.106 \\
(0.101)\end{array}$ & $\begin{array}{r}-0.059 \\
(0.116)\end{array}$ & $\begin{array}{c}-0.086 \\
(0.111)\end{array}$ \\
\hline between 20,000 and 25,000 INR & & $\begin{array}{r}-0.145 \\
(0.098)\end{array}$ & $\begin{array}{l}-0.170^{\star} \\
(0.099)\end{array}$ & $\begin{array}{r}-0.107 \\
(0.112)\end{array}$ & $\begin{array}{r}-0.125 \\
(0.105)\end{array}$ \\
\hline above 25,000 INR & & $\begin{array}{r}0.177 \\
(0.126)\end{array}$ & $\begin{array}{r}0.168 \\
(0.128)\end{array}$ & $\begin{array}{c}0.256^{\star} \\
(0.149)\end{array}$ & $\begin{array}{r}0.192 \\
(0.145)\end{array}$ \\
\hline Contribution to hh income (share) & & $\begin{array}{r}-0.011 \\
(0.022)\end{array}$ & $\begin{array}{r}-0.011 \\
(0.023)\end{array}$ & $\begin{array}{r}-0.005 \\
(0.026)\end{array}$ & $\begin{array}{r}-0.008 \\
(0.025)\end{array}$ \\
\hline \multicolumn{6}{|l|}{ Religion, ref: Hindu } \\
\hline Muslim & & & $\begin{array}{r}-0.077 \\
(0.069)\end{array}$ & $\begin{array}{r}-0.111 \\
(0.080)\end{array}$ & $\begin{array}{c}-0.122^{\star} \\
(0.074)\end{array}$ \\
\hline Sikh & & & $\begin{array}{r}-0.175 \\
(0.239)\end{array}$ & $\begin{array}{c}-0.253 \\
(0.252)\end{array}$ & $\begin{array}{c}-0.253 \\
(0.253)\end{array}$ \\
\hline Believes fate in god's hands $(=1)$ & & & $\begin{array}{r}0.037 \\
(0.075)\end{array}$ & $\begin{array}{r}0.016 \\
(0.087)\end{array}$ & $\begin{array}{r}0.075 \\
(0.080)\end{array}$ \\
\hline Caste $(=1)$ & & & $\begin{array}{r}-0.077 \\
(0.055)\end{array}$ & $\begin{array}{r}-0.028 \\
(0.059)\end{array}$ & $\begin{array}{r}-0.034 \\
(0.058)\end{array}$ \\
\hline \multicolumn{6}{|l|}{ Driving behaviors and safety perceptions } \\
\hline Uses motorbike to commute $(=1)$ & & & & $\begin{array}{r}0.015 \\
(0.079)\end{array}$ & \\
\hline Never uses ring roads $(=1)$ & & & & $\begin{array}{l}0.244^{\star \star} \\
(0.107)\end{array}$ & \\
\hline \# of persons on motorbike & & & & $\begin{array}{r}-0.073 \\
(0.047)\end{array}$ & \\
\hline Confident in own driving ability $(=1)$ & & & & $\begin{array}{r}-0.066 \\
(0.062)\end{array}$ & \\
\hline Took driving lessons $(=1)$ & & & & $\begin{array}{r}0.046 \\
(0.060)\end{array}$ & \\
\hline Underest. ann. road inj. $(=1)$ & & & & $\begin{array}{r}-0.062 \\
(0.063)\end{array}$ & \\
\hline Experienced road traffic accident $(=1)$ & & & & $\begin{array}{r}-0.035 \\
(0.110)\end{array}$ & \\
\hline Owns motorbike $(=1)$ & & & & $\begin{array}{r}-0.229 \\
(0.148)\end{array}$ & \\
\hline $\begin{array}{l}\text { Size of motorbike in cc, ref: } 100 \mathrm{cc} \text { or } 1 \\
\text { between } 100 \mathrm{cc} \text { and } 150 \mathrm{cc}\end{array}$ & & & & $\begin{array}{r}-0.042 \\
(0.071)\end{array}$ & \\
\hline above $150 \mathrm{cc}$ & & & & $\begin{array}{r}0.039 \\
(0.092)\end{array}$ & \\
\hline Has health insurance $(=1)$ & & & & $\begin{array}{l}0.009^{\star \star \star} \\
(0.003)\end{array}$ & \\
\hline Type of trips, ref: Short distance trip & & & & & \\
\hline Long distance trip & $\begin{array}{l}0.134^{\star \star \star} \\
(0.015)\end{array}$ & $\begin{array}{l}0.141^{\star \star \star} \\
(0.016)\end{array}$ & $\begin{array}{l}0.142^{\star \star \star} \\
(0.016)\end{array}$ & $\begin{array}{l}0.165^{\star \star \star} \\
(0.020)\end{array}$ & $\begin{array}{l}0.155^{\star \star \star} \\
(0.018)\end{array}$ \\
\hline Neighbourhood trip & $\begin{array}{l}-0.035^{\star \star} \\
(0.014)\end{array}$ & $\begin{array}{l}-0.038^{\star \star} \\
(0.015)\end{array}$ & $\begin{array}{l}-0.040^{\star \star \star} \\
(0.015)\end{array}$ & $\begin{array}{l}-0.048^{\star \star \star} \\
(0.018)\end{array}$ & $\begin{array}{l}-0.045^{\star \star \star} \\
(0.017)\end{array}$ \\
\hline Interviewer fixed effects & yes & yes & yes & yes & yes \\
\hline Pseudo $\mathrm{R}^{2}$ & 0.125 & 0.158 & 0.168 & 0.223 & 0.189 \\
\hline Observations & 1369 & 1324 & 1294 & 1178 & 1178 \\
\hline
\end{tabular}


Table A3: Helmet use and speed level chosen by drivers, simultaneous equation system, marginal effects

\begin{tabular}{|c|c|c|c|c|c|}
\hline & $(1)$ & $(2)$ & $(3)$ & $(4)$ & $(5)$ \\
\hline \multicolumn{6}{|l|}{ HELMET USE } \\
\hline Risk aversion score & $\begin{array}{r}0.032 \\
(0.022)\end{array}$ & $\begin{array}{r}0.027 \\
(0.022)\end{array}$ & $\begin{array}{l}0.036^{\star} \\
(0.021)\end{array}$ & $\begin{array}{c}0.036^{\star} \\
(0.021)\end{array}$ & $\begin{array}{l}0.056^{\star \star} \\
(0.022)\end{array}$ \\
\hline \multicolumn{6}{|l|}{ Socio-demographic characteristics } \\
\hline \multirow[t]{2}{*}{ Age (in years) } & & -0.001 & -0.000 & 0.001 & -0.000 \\
\hline & & $(0.002)$ & $(0.002)$ & $(0.001)$ & $(0.002)$ \\
\hline \multirow[t]{2}{*}{ Married $(=1)$} & & 0.028 & 0.033 & 0.030 & 0.033 \\
\hline & & $(0.041)$ & $(0.042)$ & $(0.044)$ & $(0.043)$ \\
\hline \multirow[t]{2}{*}{ Number of children } & & 0.015 & 0.006 & 0.001 & 0.013 \\
\hline & & $(0.015)$ & $(0.013)$ & $(0.013)$ & $(0.014)$ \\
\hline \multirow{2}{*}{ Household head $(=1)$} & & 0.032 & 0.028 & 0.008 & 0.001 \\
\hline & & $(0.044)$ & $(0.044)$ & $(0.043)$ & $(0.049)$ \\
\hline \multirow[t]{2}{*}{ Household size } & & $-0.015^{\star \star}$ & $-0.013^{\star \star}$ & $-0.017^{\star \star \star}$ & $-0.016^{\star \star \star}$ \\
\hline & & $(0.006)$ & $(0.006)$ & $(0.006)$ & $(0.006)$ \\
\hline \multicolumn{6}{|c|}{ Education, ref: Primary-secondary education } \\
\hline Illiterate & & $\begin{array}{l}-0.135^{\star \star \star} \\
(0.045)\end{array}$ & $\begin{array}{l}-0.111^{\star \star} \\
(0.049)\end{array}$ & $\begin{array}{l}-0.104^{\star} \\
(0.057)\end{array}$ & $\begin{array}{l}-0.114^{\star \star} \\
(0.051)\end{array}$ \\
\hline Tertiary education & & $\begin{array}{l}0.055^{\star \star} \\
(0.026)\end{array}$ & $\begin{array}{r}0.040 \\
(0.025)\end{array}$ & $\begin{array}{r}0.024 \\
(0.025)\end{array}$ & $\begin{array}{r}0.038 \\
(0.025)\end{array}$ \\
\hline \multicolumn{6}{|c|}{ Household monthly income, ref: less than 5,000 INR } \\
\hline \multicolumn{2}{|c|}{ between 5,000 and 10,000 INR } & n.e. & n.e. & n.e. & n.e. \\
\hline \multicolumn{2}{|l|}{ between 10,000 and 15,000 INR } & n.e. & n.e. & n.e. & n.e. \\
\hline \multicolumn{2}{|l|}{ between 15,000 and 20,000 INR } & n.e. & n.e. & n.e. & n.e. \\
\hline \multicolumn{2}{|l|}{ between 20,000 and 25,000 INR } & n.e. & n.e. & n.e. & n.e. \\
\hline \multicolumn{2}{|l|}{ above $25,000 \mathrm{INR}$} & n.e. & n.e. & n.e. & n.e. \\
\hline \multicolumn{2}{|l|}{ Contribution to hh income (share) } & $\begin{array}{r}-0.002 \\
(0.013)\end{array}$ & $\begin{array}{r}-0.002 \\
(0.012)\end{array}$ & $\begin{array}{r}-0.001 \\
(0.012)\end{array}$ & $\begin{array}{r}0.000 \\
(0.012)\end{array}$ \\
\hline \multicolumn{6}{|l|}{ Religion, ref: Hindu } \\
\hline Muslim & & & $\begin{array}{r}-0.002 \\
(0.038)\end{array}$ & $\begin{array}{r}-0.024 \\
(0.039)\end{array}$ & $\begin{array}{r}-0.037 \\
(0.039)\end{array}$ \\
\hline Sikh & & & $\begin{array}{l}-0.208^{\star \star \star} \\
(0.069)\end{array}$ & $\begin{array}{l}-0.175^{\star \star \star} \\
(0.061)\end{array}$ & $\begin{array}{l}-0.182^{\star \star \star} \\
(0.067)\end{array}$ \\
\hline Believes fate in god's hands $(=1)$ & & & $\begin{array}{l}-0.016 \\
(0.037)\end{array}$ & $\begin{array}{l}-0.038 \\
(0.045)\end{array}$ & $\begin{array}{r}-0.008 \\
(0.042)\end{array}$ \\
\hline Caste $(=1)$ & & & $\begin{array}{c}-0.042^{\star} \\
(0.025)\end{array}$ & $\begin{array}{r}-0.006 \\
(0.025)\end{array}$ & $\begin{array}{r}-0.029 \\
(0.027)\end{array}$ \\
\hline \multicolumn{6}{|l|}{ Driving behaviors and safety perceptions } \\
\hline Uses motorbike to commute $(=1)$ & & & & $\begin{array}{c}0.062^{\star} \\
(0.038)\end{array}$ & \\
\hline Never uses ring roads & & & & $\begin{array}{r}0.006 \\
(0.037)\end{array}$ & \\
\hline \# of persons on motorbike & & & & $\begin{array}{l}-0.047^{\star \star} \\
(0.019)\end{array}$ & \\
\hline Confident in own driving ability $(=1)$ & & & & $\begin{array}{r}-0.024 \\
(0.028)\end{array}$ & \\
\hline Took driving lessons & & & & $\begin{array}{c}0.068^{\star \star} \\
(0.029)\end{array}$ & \\
\hline Underest. ann. road inj. $(=1)$ & & & & n.e. & \\
\hline Experienced road traffic accident $(=1)$ & & & & $\begin{array}{r}-0.006 \\
(0.040)\end{array}$ & \\
\hline Owns motorbike $(=1)$ & & & & $\begin{array}{r}-0.012 \\
(0.058)\end{array}$ & \\
\hline $\begin{array}{l}\text { Size of motorbike in cc, ref: } 100 \mathrm{cc} \text { or } 1 \\
\text { between } 100 \text { and } 150 \mathrm{cc} \\
\text { above } 150 \mathrm{cc}\end{array}$ & & & & $\begin{array}{l}\text { n.e. } \\
\text { n.e. }\end{array}$ & \\
\hline Has health insurance $(=1)$ & & & & $\begin{array}{c}0.003^{\star \star} \\
(0.001)\end{array}$ & \\
\hline Type of trips, ref: Short distance trip & & & & & \\
\hline Long distance trip & $\begin{array}{l}0.233^{\star \star \star} \\
(0.023)\end{array}$ & $\begin{array}{c}0.230^{\star \star \star} \\
(0.022)\end{array}$ & $\begin{array}{c}0.230^{\star \star \star} \\
(0.023)\end{array}$ & $\begin{array}{c}0.259^{\star \star \star} \\
(0.025)\end{array}$ & $\begin{array}{c}0.260^{\star \star \star} \\
(0.025)\end{array}$ \\
\hline Neighbourhood trip & $\begin{array}{l}-0.038^{\star \star \star} \\
(0.014)\end{array}$ & $\begin{array}{l}-0.043^{\star \star \star} \\
(0.014)\end{array}$ & $\begin{array}{l}-0.044^{\star \star \star} \\
(0.014)\end{array}$ & $\begin{array}{l}-0.050^{\star \star \star} \\
(0.015)\end{array}$ & $\begin{array}{l}-0.048^{\star \star \star} \\
(0.015)\end{array}$ \\
\hline Interviewer fixed effects & yes & yes & yes & yes & yes \\
\hline Observations & 1367 & 1328 & 1295 & 1160 & 1160 \\
\hline
\end{tabular}

Notes: n.e. stands for not estimable. ${ }^{\star} \mathrm{p}<0.10,{ }^{\star \star} \mathrm{p}<0.05,{ }^{\star \star \star} \mathrm{p}<0.01$. 